\title{
Gender, Equity, and Indigenous Women's Health in the Americas
}
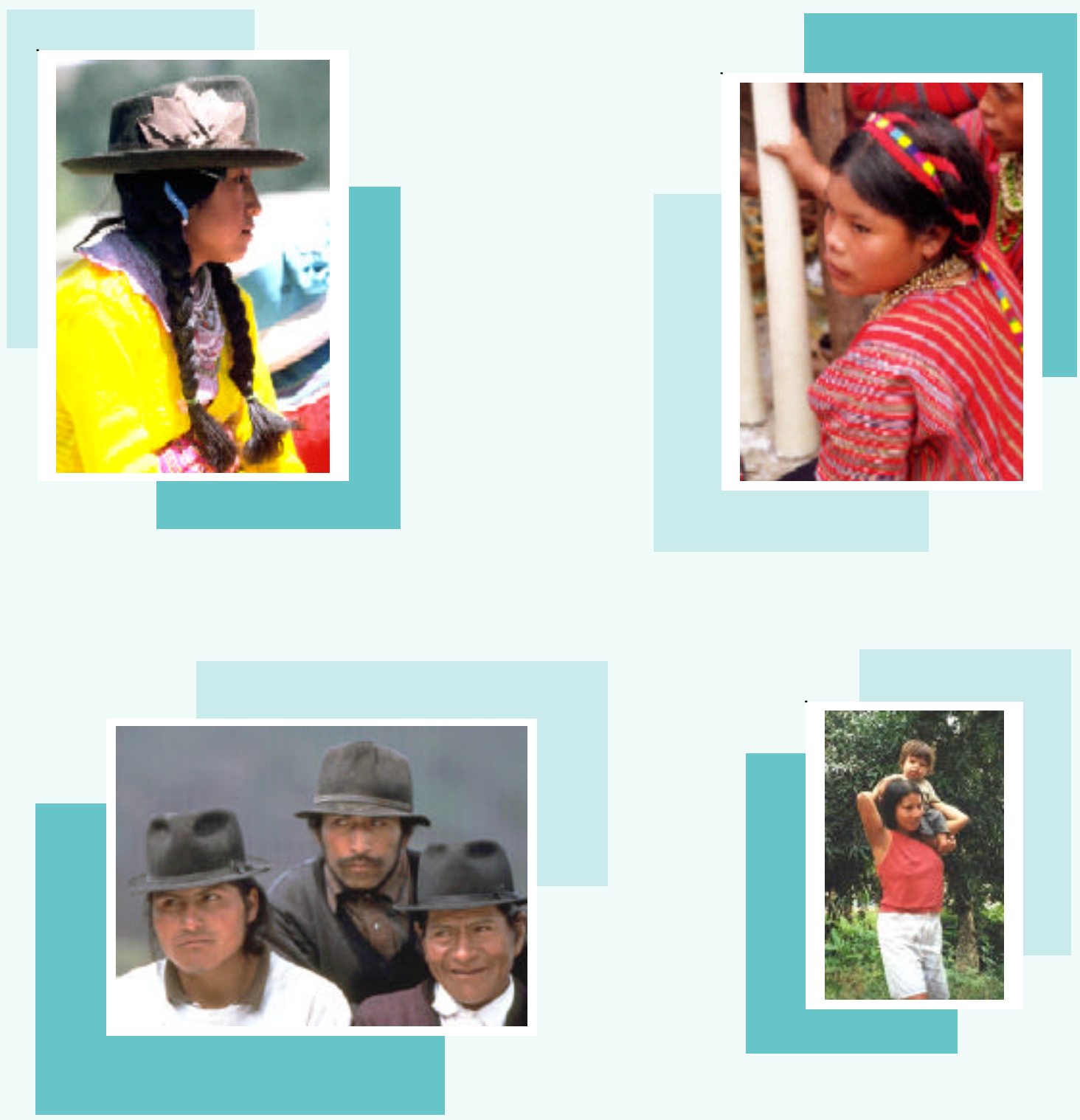

Gender and Health Unit

Pan-American Health Organization 


\section{Gender, Equity, and Indigenous Women's Health in the Americas}

Prepared by Jessica Hughes

for

The Gender and Health Unit

with the Health Services Organization Unit

Pan-American Health Organization

Regional Office of the World Health Organization

March 2004

Washington DC 


\section{Contents}

1. Introduction ...................................................................

2. Applying a Gender Analysis to Indigenous Women's Health ................. 2

3. Demographic Profile .......................................................

4. Indigenous Women's Social Status.......................................... 4

4.1. Division of Labor ................................................... 4

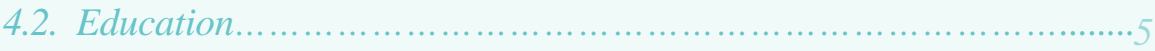

4.3. Decision-making Power................................................. 6

4.4. Violence against Women ................................................ 7

5. Indigenous Women's Health in the Americas.............................. 8

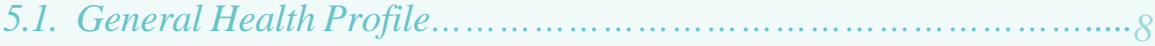

5.2. Determinants of Health ................................................ 9

5.2.1. Community Infrastructure ..................................... 9

5.2.2. Social Instability and Change................................... 10

5.2.3. Access to Employment and Women's Labor.......................11

5.2.4. Access to Health Care ........................................... 12

5.3. Health Outcomes among Indigenous Women......................... 16

5.3.1. Reproductive Health........................................... 16

5.3.2. Occupational Health.......................................... 19

5.3.3. Communicable Diseases........................................ 19

5.3.4. Non-communicable Diseases.................................. 20

6. Addressing Indigenous Women's Health................................ 21

6.1. International and National Legal Frameworks.......................... . .

6.2. International Cooperation............................................ 22

6.3. Indigenous Women Organizing......................................... 22

6.4. Recommendations............................................... 23

6.4.1. For Health Policy Planners \& Donor Institutions..................24

6.4.2. For Health Workers and Project Managers...................... 25

7. Conclusions............................................................ 26

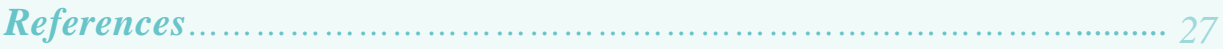

Front Cover Images

1. Woman in yellow - Copyright PAHO, Photographer Carlos Gaggero

2. Guatemalan indigenous girl - Copyright PAHO, Photographer: Carlos Gaggero

3. Quechua-speaking communities in the high Sierra near the town of Otavalo often lack access to reproductive health and family planning services. The Jambi Huasi provides such education to both men and women in remote communities.

Reproduced with authorization from UNFPA (Alvaro Serrano)

Photographer: Revesz Tamas. http://www.unfpa.org/focus/ecuador/photos.htm

4. Shipibo-Conibo woman with child

Copyright, Raintree Nutrition, Inc. Source: http://www.rain-tree.com/ 


\section{Introduction}

Indigenous women's gender roles and their relationships with men, their communities, and society as a whole shape both their ability to achieve good health and their quality of life.

Men and women have different health profiles and therefore different health needs, as a result of their different biological constitutions and their distinct status in society. Indigenous women are triply disadvantaged throughout most of the Region due to their a) ethnicity, b) sex, and c) predominantly rural residency patterns. Despite having a lower rate of mortality than indigenous men, indigenous women's rate of morbidity is higher, mainly due to their triple burden ${ }^{1}$ of reproductive, domestic, and productive labor. The particular tasks that indigenous women undertake and their generally, but not consistently unequal power relationships with men often place them at a higher risk for health complications. In relation to non-indigenous women in the region, indigenous women have both higher morbidity and mortality rates, which result from lack of access

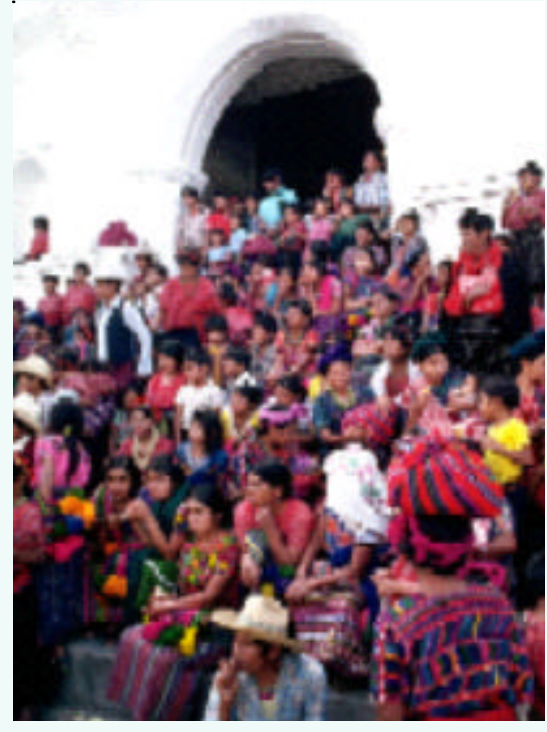

Guatemala - Indigenous people gather for a public event Carlos Gaggero

to health care, education and employment, as well as discrimination and cultural misunderstanding. Programs and policies that target indigenous peoples' health and women's health have historically been designed and implemented separately resulting in an absence of programs that deal specifically with the distinct health needs of indigenous women.

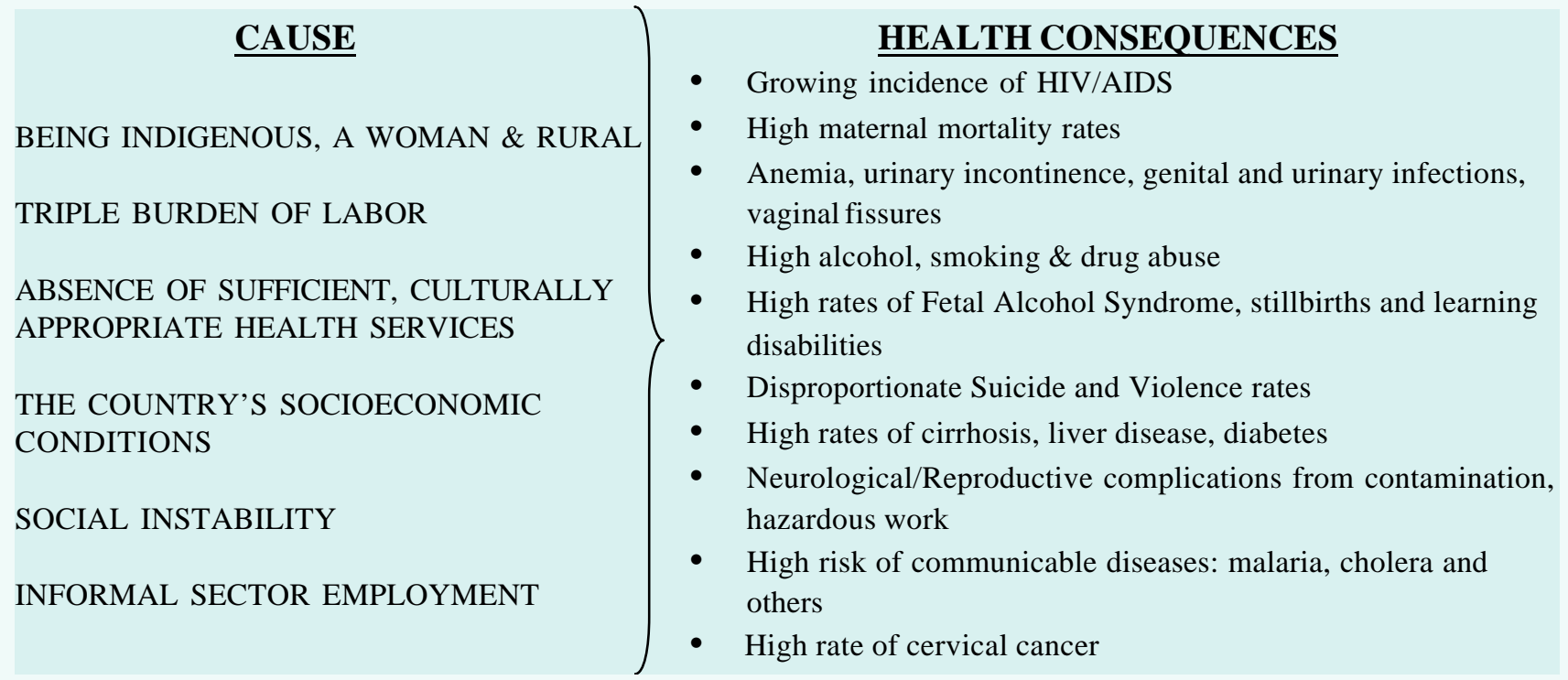

This paper will explore the specific determinants of indigenous women's health status and situation from a gender roles and relations perspective. It will begin by examining the social status and health determinants of indigenous women throughout the Americas, using available data and examples from seven countries (Canada, Ecuador, Guatemala, Mexico, Nicaragua, Peru, and the United States). The paper will continue with a look at health outcomes among indigenous women, identifying the major causes of morbidity and mortality for selected

${ }^{1}$ The "Triple Burden of Labor" refers to women's three spheres of labor: productive labor (wage earning or income generating activities), reproductive labor (childbirth and care), and domestic labor (food preparation, washing, cooking, cleaning, water and firewood collection etc.) 
communities. Finally, the paper will outline the challenges and opportunities for addressing indigenous women's health and gender equity in the Americas, using specific case studies and existing best practices to support a comprehensive set of recommendations.

It is hoped that this paper will spark more discussion on the ways in which the international community, practitioners and the governments of the Region can work with indigenous peoples to provide accessible, high quality, and culturally-sensitive health services to indigenous communities. This will require a deeper understanding of how the interplay between sex, ethnicity, culture, socioeconomic status, age, and region of residence impacts the health of indigenous peoples. To date, academic research and development work have largely neglected the specific health needs of indigenous populations, even though as a group they often have the worst health profiles and the poorest access to health services among their respective national populations. Furthermore, the lack of socio-economic and health data disaggregated by both ethnicity and sex in most of the countries of the Americas, compounded by the scarcity of research on the impact of traditional indigenous culture and gender roles on women's health status, makes the analysis of indigenous women's health problematic at best.

As cultural practices and beliefs concerning gender roles and relationships vary among indigenous societies in the region, the examples given throughout this paper should not necessarily be generalized to all indigenous communities. Nevertheless, important similarities in both cultural beliefs and women's gender roles and health status do exist among the countries reviewed. From these examples it is possible to draw conclusions and make recommendations about common health status, determinants and outcomes which can be utilized in advocacy for improving indigenous women's health.

\section{Applying a Gender Analysis to Indigenous Women's Health}

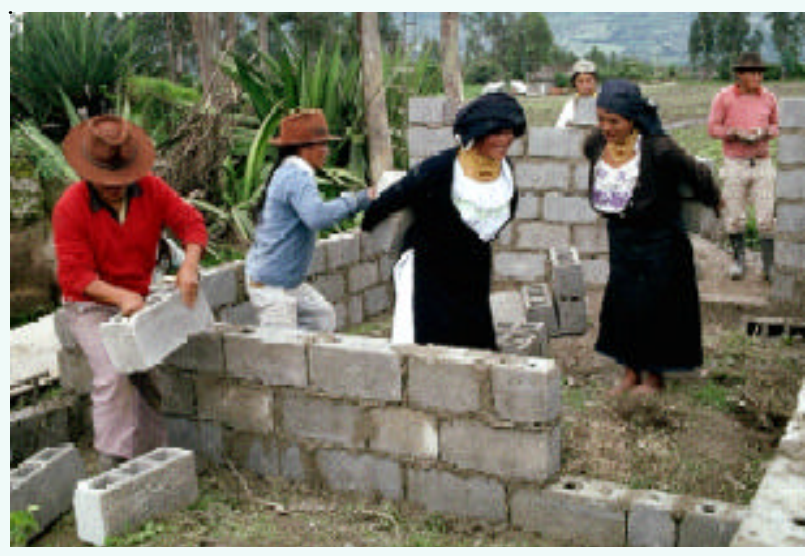

Ecuador - Indigenous women assisting in construction Carlos Gaggero
Gender ${ }^{2}$ is one of the primary axes around which social life is organized, and plays a central role - along with ethnicity, culture, socio-economic status, age and region of residence- in determining men and women's social status and access to resources.

A gender-based analysis ${ }^{3}$ of health looks at men and women's distinct social roles, the balance of power between them, and how these affect their physical and mental health profiles, including: determinants of health; health outcomes; and access to health care and other resources. Thus, a gender analysis of indigenous women's health draws out the ways that indigenous women and men's traditional roles and relationships impact their ability to attain good health, highlighting the cultural, economic, social and political causes behind indigenous women's consistently high rates of both morbidity and mortality. It also demonstrates the wide variety of realities and experiences that exist among indigenous women in the Americas.

Practical Needs vs. Strategic Interests - Identifying indigenous women's needs and interests is complicated by the intersection of sex and ethnicity. While their sex and gender roles may determine some of their health needs, others are determined by their status as indigenous people within a larger population, and it is not always

${ }^{2}$ While "sex" refers to the biological difference between women and men, gender refers to the social significance attributed to these biological differences. Gender differences are fundamentally expressed in the division of power and labor between women and men. Gender itself is a relational concept that looks not at women or men, but at the unequal relations between the two, particularly with respect to the distribution of power and its effect on men and women's social status, access to resources, and health profiles.

${ }^{3}$ PAHO, 2002a 
easy to separate the two variables for analysis and intervention. Indigenous women themselves may not identify gender inequities as a concern - preferring instead to address issues that affect their entire community.

Caroline Moser's framework ${ }^{4}$ provides a useful way of conceptualizing indigenous women's needs and interests. Practical needs are those which must be met for survival - such as water, food, clothing, shelter, and basic health care. Indigenous women's practical needs are determined primarily by their status as indigenous people; often poorer and more marginalized than the general population. Strategic interests on the other hand are related to the quality of women's lives, their status within the community, and their sense of self-esteem. Indigenous women's strategic interests are more likely to be determined by their gender roles and relations their status within the indigenous community. Because indigenous women's practical needs are more immediate, they themselves may choose to focus on meeting them and improving the status of the indigenous community as a whole, rather than emphasizing their strategic interests. Thus some indigenous women have rejected the concept of gender as irrelevant and divisive, preferring to focus on the practical needs of their community before focusing on their own status within that community.

Since the main goal of conducting a gender analysis is to identify inequalities in order to address and eliminate them, it is essential that a gender analysis of indigenous women's health allows women themselves to define their health needs and interests. Indigenous communities' concepts of good health and determinants of illness are distinct from Western notions of physical and mental ailments, and indigenous women include spiritual health and their relationship to their environment as important determinants of their own health status. ${ }^{5}$

\section{Demographic Profile}

There are approximately 42 million indigenous people living in the Americas from 400 different groups, which comprise $6 \%$ of the total population of the American continent and almost 10\% of the population of LAC (see Table 1). ${ }^{6}$ Of these, approximately $80 \%$ live in Central America and the central Andes. The majority of indigenous people live in Mexico (12 million or 14\% of the national population), Guatemala (5.3 million, or 66\%), Peru (9.3 million or $47 \%$ ), Bolivia (4.9 million or $71 \%$ ) and Ecuador (4.1 million or $43 \%)^{7}$

The high concentration of indigenous people in many of these countries suggests that their health concerns should be a national priority. However, as a group indigenous peoples often have the worst health profiles, highest rates of morbidity and mortality, and the least access to health services among their national populations. This analysis will focus on three distinct regions, the United States and Canada, Central America and the Andean Region, because each area has distinct socio-economic, geographic, and cultural realities.

\section{Table 1 - Indigenous Peoples of the Americas}

\begin{tabular}{|c|c|c|c|c|c|c|c|c|c|}
\hline Country & \# of indigenous & $\%$ of total & Main areas of & \multicolumn{2}{|c|}{ Life expectancy at birth } & \multicolumn{4}{|c|}{$\%$ of indigenous people: } \\
\hline & people & pop. & residency & Men & Women & \multicolumn{2}{|c|}{$<25 \mathrm{yrs}^{8}$} & $>6$ & yrs \\
\hline USA & 3.1 million $^{9}$ & 1.5 & $\begin{array}{l}30 \% \text { reservations } \\
30 \% \text { urban } \\
30 \% \text { between both }\end{array}$ & N/A & N/A & \multicolumn{2}{|c|}{$\begin{array}{l}49.6^{10} \\
34.8^{* 11}\end{array}$} & \multicolumn{2}{|c|}{$\begin{array}{l}65 \\
15.7 *\end{array}$} \\
\hline Canada & 799,010 & 3.0 & $30 \%$ reservations $^{12}$ & $\begin{array}{l}68.9^{13} \\
76.3^{*}\end{array}$ & $\begin{array}{l}76.6 \\
81.8^{*}\end{array}$ & \multicolumn{2}{|c|}{ N/A } & \multicolumn{2}{|c|}{ N/A } \\
\hline Guatemala & 5.3 million $^{14}$ & $66^{15}$ & $\begin{array}{l}\text { Northwest and Northern } \\
\text { Depts. }\end{array}$ & \multicolumn{2}{|c|}{$\begin{array}{l}\text { Approx. } 60 \text { years of age for } \\
\text { both men and women }{ }^{16} 17\end{array}$} & \multicolumn{2}{|c|}{ N/A } & \multicolumn{2}{|c|}{ N/A } \\
\hline Ecuador & 4.1 million $^{18}$ & 43.0 & Andean region & N/A & N/A & \multicolumn{2}{|c|}{ N/A } & \multicolumn{2}{|c|}{ N/A } \\
\hline \multirow{2}{*}{ Peru } & \multirow[t]{2}{*}{9.2 million } & \multirow[t]{2}{*}{47.0} & \multirow[t]{2}{*}{ Amazonian region } & \multirow[t]{2}{*}{ N/A ${ }^{19}$} & \multirow[t]{2}{*}{ N/A } & $<14$ yrs & $15-($ & 4 yrs & $65+y r s$ \\
\hline & & & & & & $\begin{array}{l}49.67 \\
37.0^{*}\end{array}$ & $\begin{array}{l}48 \\
58\end{array}$ & $1 *$ & $\begin{array}{l}1.5 \\
\mathrm{~N} / \mathrm{A}\end{array}$ \\
\hline
\end{tabular}




\section{Indigenous Women's Social Status}

My husband used to say, 'There is no reason for me to iron clothes because I have sisters to do that'... and sometimes he would hit me. At that time, we didn't know that men, like women, should also be responsible for doing women's work [sic]....we used to say, "what will people think if they find out a man is ironing?' They will speak badly of us if he is cooking...now my son....says to his sister, 'Lucia, I need my pants cleaned', and I say to him, 'son, do not order people around please, you are also responsible for washing pants and shirts and hanging them out to dry ...there is no reason for you to order girls around'... we have to teach them like this from childhood [to share the work] so they learn how to treat their partner [women] as she deserves ("llevar a su mujer bien bonito").

Kichwa Woman $^{22}$
While the social construction of gender may differ between indigenous communities and the general population and among indigenous communities themselves, this does not necessarily reduce the relevance of gender as a determinant of health status. Indigenous communities, like the general population, have specific arlturedl roles and norms of behaviour for both men and women, some of which pre-date colonization, and some of which have been integrated into indigenous societies as a result of colonization.

Gender defines two separate but complementary economic and social dimensions: the publicproductive-remunerated sphere; and the private-

reproductive-unremunerated sphere. Historically women have been responsible for the reproductive/private sphere, which encompasses childbirth and childcare, washing, cooking, collecting water and fuel etc. Men have been responsible for the productive/public sphere, which comprises paid work and community and national decision-making and priority-setting, and which has been assigned a greater economic and social value. The value of women's reproductive labor, though essential to the national economy and the reproduction of the labor force itself, has been ignored in national economic and social assessments.

In practice however, the distinction between the two spheres is not as clear. Indigenous women do participate in productive labor and community decision-making, though they are not always paid and their participation is often defined by their gender roles.

\subsection{Indigenous Women's Social Status}

Indigenous women and men describe the traditional division of labor in their communities as complementary and reciprocal - men and women perform different but complementary functions as a result of their biological differences. However, this characterization ignores the fact that many indigenous women do participate equally in productive community activities, but without receiving any of the benefits. Women are responsible for a triple burden of productive (farming, crafts and other informal sector

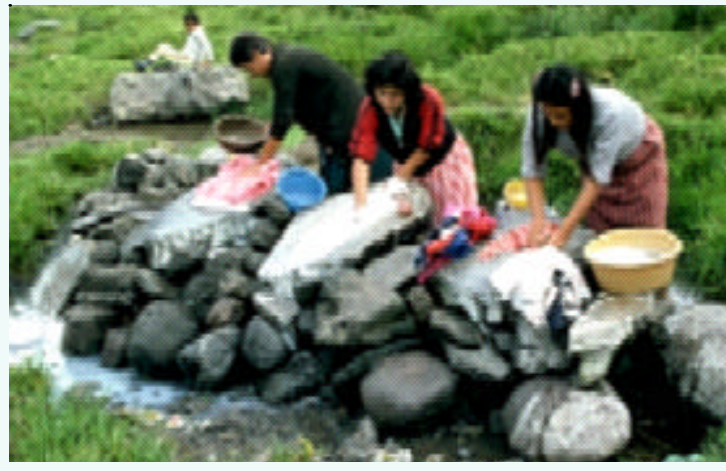

Guatemala - Women washing clothes at the stream Carlos Gaggero

\footnotetext{
${ }^{4}$ Moser, 1993

${ }^{5}$ Almost every study referenced in this paper cites the importance of holistic/traditional beliefs about health and spirituality to the health and development of indigenous communities.

${ }^{6}$ PAHO, 1998a, 95.6

${ }^{6}$ PAHO,

${ }^{8}$ For the USA only, the figures represent $\%$ of indigenous women, not people under and above these ages.

${ }^{9}$ PAHO, 2002b, 536

${ }^{10}$ U.S. Department of Health and Human Services, 1999, 2.

${ }^{11}$ All figures with an asterisk* denote the equivalent figures for the non-indigenous populations in the selected countries.

${ }^{12}$ Health Canada, 1999, .5-6.

${ }^{13}$ Health Canada, 2003, 14

${ }^{14}$ The World Bank cites 5.3 million, or $66 \%$, of the total population as being indigenous (Correia and Pena, 2002, 3).

${ }^{15}$ PAHO figures are at $48 \%$ of the total population. (PAHO, 2002b, 312).

${ }^{16}$ This figure is an estimate for the departments with the highest concentrations of indigenous people and is an average of both men and women's life expectancy. There were no sex disaggregated figures available.

${ }^{17} \mathrm{PAHO} /$ WHO/IADB, 1997, 10

${ }^{18}$ PAHO, 1998a, 96. Figures for Peru also are found in this source.

${ }^{19}$ This data is not available, but we can assume that it is less than the national average of 68 years of age due to the small percentage of people over 65 years in the indigenous population.

${ }^{20}$ Culture here refers to both traditional/pre-Hispanic customs, and customs which have been adopted or modified by the influence of dominant/colonizing cultures - an example of this would be the distinction between patriarchy (a pre-Hispanic facet of many indigenous societies) and machismo (norms of behaviour inherited from the dominant/colonizing culture).
} 
labor), reproductive (pregnancy and childcare) and domestic (food preparation, work in kitchen gardens, housework) labor. Women's heavy workload is both time-consuming and arduous, making it less likely that women will have time for other activities such as education, participation in community decision-making and seeking healthcare for themselves or their children.

Kichwa, Shipibo, and Maya ${ }^{21}$ women participate equally with the planting, cultivation and harvesting of crops, and $70 \%$ of Kichwa women devote as much time as men to the marketing of their farm products. Kichwa women's heavy workload appears to be accompanied by more decision making power than in Shipibo and Mayan communities. Kichwa women average 47 hours a week in agricultural labor, and are leaders of community labor efforts. ${ }^{22}$ Although Kichwa women were and are still primarily responsible for domestic labor, they claim that the recent efforts of local organized groups to sensitize women and men to gender discrimination have led to an increase in mothers teaching their sons to wash and cook, and a reduction in the tendency to give sons power over their sisters. ${ }^{23}$ However, other women in the same communities expressed their

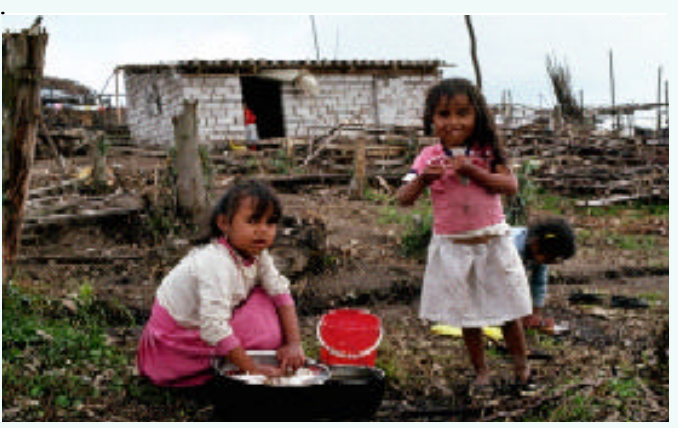

Ecuador - Girls start assisting with housework from an early age Carlos Gaggero

\section{Guatemala - Women share in farming tasks} Carlos Gaggero

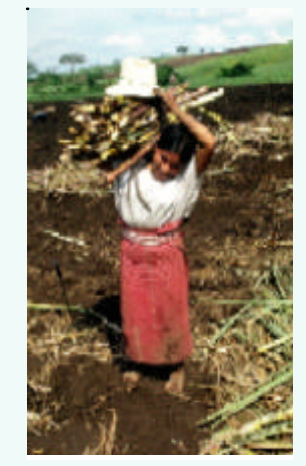
husband's reluctance to assume any household tasks.

\begin{abstract}
"...we no longer receive education in the way our parents did, instead,[an]other education system has arrived [in our communities]: this starts inculcating... [our men] to be 'machistas', to be dominant, all of which has always impaired women."

Magdalena Fueres works with Cotacachi Women in Ecuador.
\end{abstract}

\subsection{Education}

Both education and employment are highly correlated with good health. If a mother has access to income, she is more able to afford medicines and health services that she and her family need. If she is aware of her options (contraceptive, nutritional, sanitary), then she is better able to protect her family's health and follow preventive health measures to avoid illness.

Education to indigenous people is not simply about acquiring Western knowledge, customs and languages, but also about obtaining the historical and cultural knowledge they need to participate actively in their traditional communities. School is often perceived by indigenous communities as perpetuating the patriarchal system, and enforcing "western values" like oppositional gender roles, in detriment to the duality (complementarity) of gender roles upheld by indigenous cultures. ${ }^{24}$

Despite the fact that women in general are showing higher educational performance than men in the Region, indigenous women continue to show lower literacy rates and less completed school years than men. In LAC, indigenous women's exclusion from education is a result of their increased burden of domestic labor, their age, and their lower rates of bilingualism. ${ }^{25}$

\footnotetext{
${ }^{21}$ The Kichwa and Shipibo Communities are native to Ecuador and Peru, whereas the Mayans are concentrated primarily in Guatemala

${ }^{22}$ Vallejo Real, Y, 2002, 40.

${ }^{23}$ Ibid (translation by author), 27

${ }^{24}$ Ibid., 13.

${ }^{25}$ Indigenous women in many of the rural areas do not speak Spanish, making literacy learning in the latter language more difficult for them than men, whose mobility and migration has led to their higher proficiency in Spanish.
} 


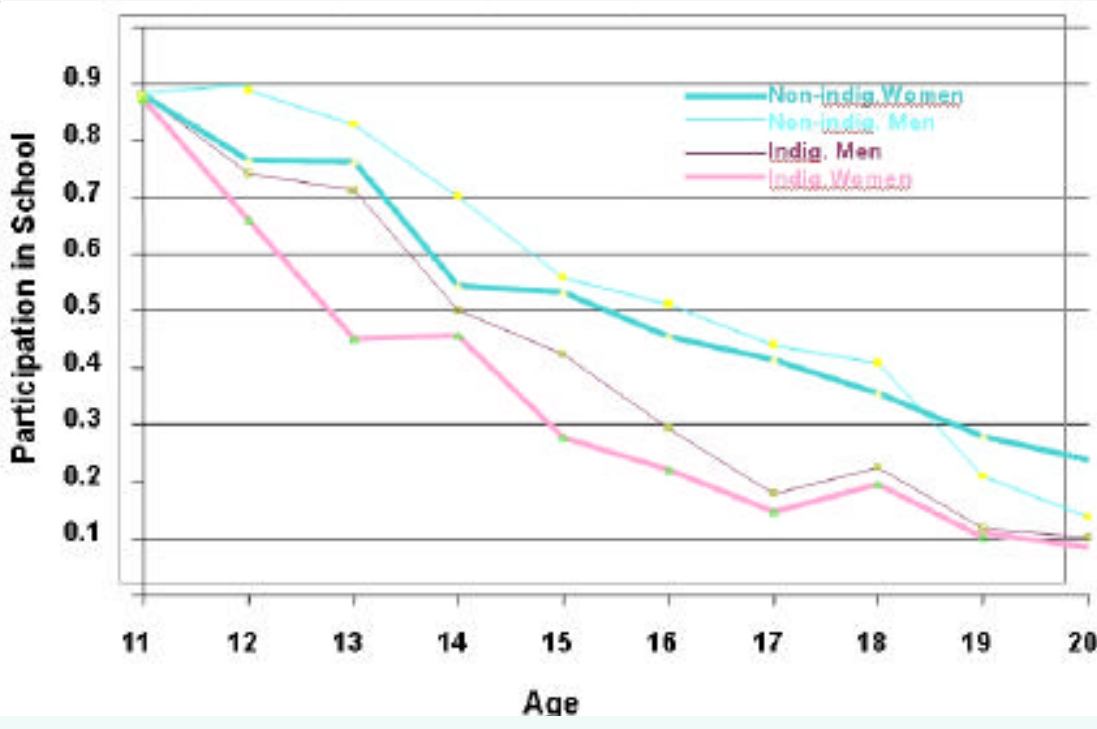

Figure 1 - Indigenous Women's Participation in Education Source: Guatemala 1998
Young girls start assisting their mothers very early on, often resulting in the indefinite postponement of their education, and preference is given to boys' attending school. In Ecuador, 53\% of indigenous women are illiterate compared to $35 \%$ of indigenous men. ${ }^{26}$ In the Sierra region, more than a quarter of women cannot read or write, compared to $14 \%$ of men. ${ }^{27}$ In Peru, $43.3 \%$ of indigenous women have no education and $30.8 \%$ of Shipibo women are illiterate. ${ }^{28}$ In Guatemala (see figure 1), whereas indigenous men complete an average of 1.9 years of schooling, indigenous women complete 0.9 years and $64 \%$

of rural women have no schooling at all. ${ }^{29}{ }^{30}$ In Canada, only $2.9 \%$ of Aboriginal women held a university degree in 1990 , while $10.9 \%$ of Canadian women overall held degrees. ${ }^{31}$

Women's low educational achievement negatively impacts their ability to obtain higher incomes, access health care services, practice safe reproductive health strategies and organize themselves effectively. Indigenous women have attested that men tend to respect them more and be prepared to listen to them when they have studied. As an Aymara woman from Peru states, "my husband respects me because I have studied at the college and make him respect my rights. Other women are not like this and cannot defend themselves." 32

\subsection{Decision-Making Power}

In many communities, indigenous men are primarily responsible for heavy farming activities, and because of the higher value placed on this type of labor they tend to dominate the public sphere, where community decisions are made.

Mayan cultures are both patriloca ${ }^{3}$ and patriarchal. Women are subordinated to the authority of their fathers and husbands, and the social control of their husbands' families. Mayan men make most household decisions, including how many children the couple will have, how the household income will be spent (even in cases when women safeguard the money or contribute to

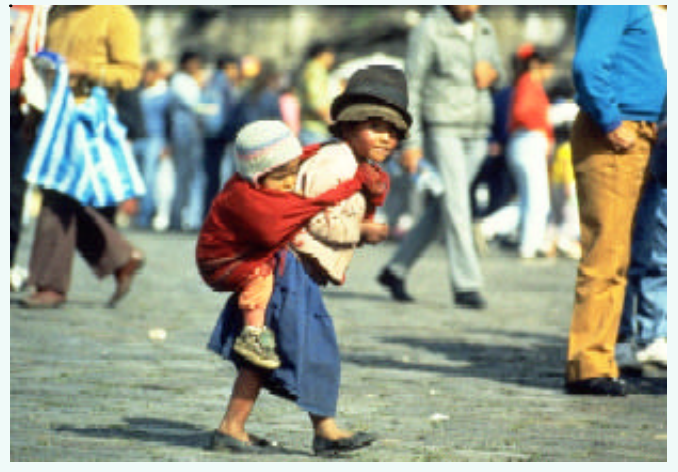

Ecuador-It is common to see girls caring for their younger siblings from a very young age Armando Waak household income),${ }^{34}$ and whether or not women can leave the house. Land is traditionally passed to the male members of the family, depriving women of an important financial resource and form of collateral to obtain credit for business creation/expansion. Women have traditionally

\footnotetext{
${ }^{26}$ World Bank 2000, 24

${ }^{27}$ Ibid.

${ }^{28}$ PAHO, 1998c., 22

${ }^{29}$ Correia, M \& Pena, V. 2002, 14

${ }^{20}$ Ibid., 14.

${ }^{31}$ Dion Stout, 1996

${ }^{32}$ Meentzen, 2000, 18.

${ }^{33}$ Patrilocal residency means that upon marriage, the woman goes to live with her husbands' family. Matrilocal residence means the man goes to live with his wife's family.

${ }^{34}$ Meentzen, 2000, 35-36
} 
been very active in community work, although not in prominent positions: they assist in community celebrations, prepare food and organize themselves for productive activities, but do not make far-reaching community decisions. Mayan women claim to be too embarrassed to speak in front of men because men tell them they are incapable of political management and discourage them from participating in community politics. ${ }^{35}$

In both Kichwa and Shipibo communities, the man is considered the head of the household and women are not given equal power in community decision-making; rather, they must obtain the consent of their husbands in questions of community concern. Among the Shipibo, residence is matrilocal, which forms an important support network for women in case of marital discord. Despite their heavy workload, women are not afforded equal rights over produce and husbands receive all the profits from women's agricultural labor. Some women have created economic independence for themselves, and gained a certain respect in their family and community through the sale of their handicrafts in the local Pucallpa market, as this income pays for the family's basic necessities. ${ }^{36}$

Kichwa marriages are usually arranged by the bride and groom's parents and women traditionally have no say in their choice of partner. Kichwa women have rights under bilateral forms of inheritance to resources, including livestock and land. They have power over domestic materials and to some degree joint decision-making power over the education of children, the use of income and investments, even though final decisions rest with the husband. ${ }^{37}$ In both contexts, the man is considered the head of the household, but in contrast to the Kichwa, Shipibo women may chose their husbands. However, unlike the Shipibo, it appears that Kichwa women's participation is valued and they exert more influence through supportive roles in public arenas. ${ }^{38}$

Many Native Americans in the South-Western United States stress that historically, women were the heads of the household and that it is the impact of colonization that has changed their position in their communities. Charon Asetoyer, a Comanche woman, has re-inscribed her people's struggle as being one to "...maintain our rightful place within our own societies." ${ }^{39}$ She insists that domestic violence rarely occurred because it is against the Comanche value system and that when it did occur the perpetrator was severely punished. She also stressed that is was women who traditionally owned livestock and all of the possessions within their households and who made the decisions over issues like trading or selling. ${ }^{40}$

In Paraguay, indigenous women argue that domestic violence in their communities has resulted from them adopting the...

...chauvinist manners of the Paraguayan man. In the old times, among the Nivaklé, women were the owners of all sexual initiative in their relationships. Invested with a certain aggressiveness for love, she could choose the man she preferred. Nowadays, the kinds of romantic relationships among white people have influenced the relationships among the indigenous people. It is no longer the woman who takes the initiative in sexual relations; it is the man. Imitating the white patron, now he dares to compel women for love 42

\subsection{Violence against Women}

In much of the Americas, the high level of domestic violence (sexual, physical, and psychological) constitutes a major health risk for indigenous women and has increased along with growing rates of alcohol abuse, poverty and unemployment among indigenous men. Aside from being a grievous violation of women's human rights, violence restricts women's ability to pursue educational, economic and political opportunities. ${ }^{41}$ Violence inflicts not only physical but psychological trauma on women and is associated with high rates of mental health disorders among indigenous women including anxiety, trauma and, in the case of the U.S. and Canada, high suicide rates. The rate of violent

\footnotetext{
${ }^{35}$ PAHO 1992,12

${ }^{36}$ Alcock, 2001.

${ }^{37}$ Vallejo Real, 2002, 22

${ }^{38}$ Ibid.

${ }^{39}$ Charon Asetoyer is the Executive Director of the Native American Women's Health Education Resource Center on the Yankton Sioux Reservation. http://www.feministcampus.org/network/chat/

$\frac{\text { chat_charon03062002.asp }}{{ }^{40} \mathrm{Ibid}}$

${ }^{41}$ Meentzen,, 2000, 22.
} 
victimization among $\mathrm{AI} / \mathrm{AN}$ females was 98 per 1,000 females, a rate significantly higher than that found among all other women. ${ }^{42}$

The Wayuu women of Venezuela also claim that domestic violence in their communities is caused by bad habits learned from occidental culture such as drug use and alcoholism. They explain than in cases of domestic violence, Wayuu women's families have the right to demand the husband pay them compensation for the damage caused to their daughter. It can be material reparation, moral reparation or women can decide if they want to separate from the man or not. ${ }^{43}$

The most significant root of domestic violence is gender inequality. Indigenous men often say they feel entitled to use sexual, physical, and/or psychological violence to control their partners' behavior if they suspect them of having an affair or believe them to be a "bad" wife. This has led to alarming rates of domestic violence and consequent mental health problems in the Region as a whole, including among indigenous communities. ${ }^{44} 45$ In Nicaragua, $32 \%$ of rural women say it is acceptable for a husband to beat his wife if he even suspects that she has been cheating on him. $75 \%$ of married Nicaraguan women have been beaten, coerced into sex or abused in some way. ${ }^{46}$ Growing unemployment among indigenous men combined with high fertility rates hinder men's ability to fulfill their role as financial provider, and violence gives them an opportunity to reaffirm their masculinity. ${ }^{47}$

In the U.S. and Canada during the last decade, suicide among young Native females has attained a level similar to that of Native males and is eight times that of the national average. ${ }^{48}$ There is a correlation between cultural breakdown, suicide and domestic violence, although more research is still needed on this issue. The available numbers on violence are an underestimation of the problem; there are many reasons why women do not report abuse or following through with the trial and punishment, and these women are not reflected in national statistics on domestic violence. Aboriginal Canadian and American Indian/Alaskan Native (AI/AN) women typically do not seek medical attention for injuries inflicted by their spouses, unless absolutely necessary. The postponement of treatment can have permanent physical health consequences or even result in the woman's death.

The persistence of domestic violence as a public health and human rights problem is a result of the absence or poor enforcement of domestic violence legislation, the inadequate social marketing of non-violent behavior, the lack of understanding of police, doctors and other public officials, and the lack of social support networks and other resources for victims of violence. Indigenous women receive little or no protection from the state, and are often unaware of their legal and human right to live free of violence. Moreover, the mainly male police, legal and judicial professionals throughout the Region often trivialize or scorn women's suffering.

\section{Indigenous Women's Health in the Americas}

\subsection{General Health Profile}

The health profiles of indigenous women in the United States ${ }^{49}$ and Canada vary considerably to those in Latin America and the Caribbean (LAC), highlighting the central role that a country's socioeconomic status, and the status of indigenous communities within that country also play in determining the health of indigenous women (see Table 2).

\footnotetext{
${ }^{42}$ HealthLink, 2002

${ }^{43}$ Meentzen, 2000, 24

${ }^{44}$ Whether domestic violence among indigenous people originates in traditional culture or not is disputed among indigenous people themselves and anthropologists, however it has become a

characteristic of indigenous societies.

${ }^{45}$ CEIMM, 2002, 22

${ }^{46}$ Guerra, 2001.

${ }^{47}$ Correia and Pena, 2002, 8 .

${ }^{48}$ Dion Stout, 1996

${ }^{49}$ Indigenous people of the U.S.A. include those residing in Alaska (not indigenous Hawaiians).
} 


\section{United States and Canada}

The major causes of morbidity and mortality for indigenous women in the US and Canada are chronic illnesses such as heart disease, cancer (breast, colon and lung) and diabetes, as well as accidents (including high rates of mortality from suicide and alcoholism), and injuries from domestic violence. In the U.S., AI/AN women have lower mortality rates for most major diseases than Caucasian women, including cancer, stroke and chronic pulmonary diseases. However, mortality from motor vehicle-related injuries, diabetes, chronic liver disease (cirrhosis) and homicide are higher than among Caucasian women.

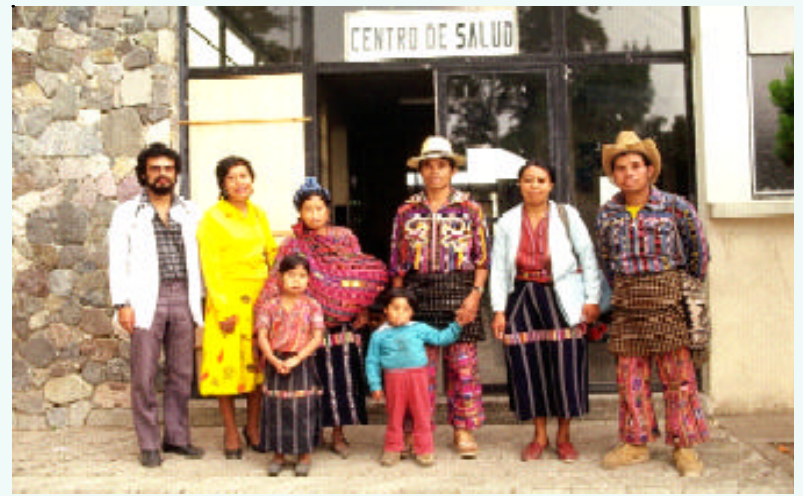

Guatemala - An indigenous family uses the local health center

Carlos Gaggero

\section{Latin America}

In the rest of the continent, the major causes of mortality for indigenous women are communicable diseases, parasites, and vector-borne illnesses including malaria and tuberculosis, acute respiratory infections, malnutrition, diarrhea and reproductive health complications, including high levels of maternal mortality, high risk maternity, high fertility, low use of prenatal health care, a growing STD and HIV/AIDS problem, and high infant mortality.

\section{Table 2 - Major Causes of Mortality among Indigenous Women}

\begin{tabular}{|c|c|c|c|c|}
\hline \multirow[t]{2}{*}{ USA } & \multirow{2}{*}{$\begin{array}{c}\text { Canada } \\
\text { (\# of deaths / 100,000) }\end{array}$} & \multicolumn{2}{|c|}{ Guatemala } & \multirow[t]{2}{*}{ Ecuador and Peru } \\
\hline & & Female & Male & \\
\hline 1. Coronary heart disease & 1. Circulatory Diseases (72.2) & $\begin{array}{l}\text { Respiratory } \\
\text { Infections }\end{array}$ & $\begin{array}{l}\text { Homicide \& } \\
\text { Civil war }\end{array}$ & Acute respiratory infections \\
\hline $\begin{array}{l}\text { 2. Cancer } \\
\text { (Lung/Breast/Colon) }\end{array}$ & $\begin{array}{l}\text { 2. Injury and poisoning } \\
\left(67.6^{51}\right)\end{array}$ & $\begin{array}{l}\text { Intestinal } \\
\text { Infections }\end{array}$ & Illnesses & $\begin{array}{l}\text { Infectious and parasitic } \\
\text { diseases (diarrhea) }\end{array}$ \\
\hline $\begin{array}{l}\text { 3. Accidents \& } \\
\text { unintentional injuries }\end{array}$ & $\begin{array}{l}\text { 3. Cancer (59.8) } \\
\left(\text { Breast/Colon/Lung }{ }^{52}\right)\end{array}$ & Perinatal causes & Accidents $^{54}$ & $\begin{array}{l}\text { Genital-urinary system } \\
\text { infections }\end{array}$ \\
\hline $\begin{array}{l}\text { 4. Diabetes }{ }^{50} \\
\text { 5. Obstetric } \\
\text { complications (remote } \\
\text { areas) }\end{array}$ & $\begin{array}{l}\text { 4. Endocrine disorders } \\
\text { (diabetes) }(17.0)^{53} \\
\text { 5. Obstetric complications (in } \\
\text { remote areas) }\end{array}$ & $\begin{array}{l}\text { Malnutrition } \\
\text { Maternal } \\
\text { mortality }\end{array}$ & & $\begin{array}{l}\text { Malnutrition } \\
\text { Cancer } \\
\text { Vaginal infections } \\
\text { Mental health problems } \\
\text { High maternal mortality } \\
55\end{array}$ \\
\hline
\end{tabular}

\subsection{Determinants of Health}

\subsubsection{Community Infrastructure}

Many indigenous communities lack access to clean water, adequate sewage systems, electricity and paved roads. The high incidence of diarrhea and other intestinal problems among indigenous communities is related to the poor quality of their water supply. ${ }^{56}$ In Peru $72 \%$ of households overall have drinkable water (public

\footnotetext{
${ }^{50}$ Williams, 2002, 589

${ }^{51}$ This figure includes the suicide rate of 12.4 per 100,000 women

${ }^{52}$ In order of prevalence.

${ }^{53}$ Approximately 2/3 of all First Nations people diagnosed with diabetes are female, which contrasts with the general population in which 2/3 of diagnosed cases are men (Health Canada, 2003, 28)

${ }^{54}$ Loughna and Vicente, 1997, 13

${ }^{5}$ PAHO, 1998b, 239

${ }^{56}$ PAHO $1998 \mathrm{c}, 38$.
} 
network inside or outside the house or communal water pump), but in indigenous communities only $5.31 \%$ have access to drinkable water, while $78 \%$ of their water comes from the river, irrigation ditch or cistern truck. Only $1.42 \%$ of indigenous communities have access to plumbing and sewage systems and only 4 of every 100 houses have electricity. ${ }^{58}$ The high incidence of respiratory infection among women is due in part to the fact that most of these women still cook and heat with combustible fuels rather than electricity, and most of their houses lack of adequate ventilation systems.

On AI/AN reservations, housing and water supply continue to be sub-standard. Without efficient ventilation systems, the combination of severe cold, tightly sealed dwellings and the possibility of overcrowding can create high levels of humidity for extended periods of time. Prolonged high humidity can promote the growth of molds, which are known to induce a variety of adverse human health effects including respiratory and immune system illnesses. ${ }^{59}$

Table 4 - Age-Adjusted Mortality Rate (per $100,000)$ for Minority-White women in the US 1996-1998 (selected causes of death)

$\begin{array}{lcc}\text { Cause } & \text { White Rate } & \text { AI/AN-White Ratio } \\ \text { Heart Disease } & 91.3 & 0.80 \\ \text { Cancer } & 108.0 & 0.70 \\ \text { Homicide } & 2.2 & 2.23 \\ \text { HIV/AIDS } & 0.8 & 1.38 \\ \text { Suicide } & 4.7 & 1.13 \\ \text { Pulmonary Disease } & 19.2 & 0.62 \\ \text { Source: Reproduced from National Center for Health Statistics } \\ \text { in Williams, D.R 2002 op cit.: } 589\end{array}$

Table 3 - Chronic Diseases among Canadian Indigenous and the General Population, by sex

\begin{tabular}{c|ccc|c}
$\begin{array}{c}\text { Chronic } \\
\text { Condition }\end{array}$ & Sex & \multicolumn{2}{c}{$\begin{array}{c}\text { Age Adjusted } \\
\text { Prevalence (\%) }\end{array}$} & $\begin{array}{c}\text { Ratio } \\
\text { FN \& I /Cdn. }\end{array}$ \\
\hline \multirow{2}{*}{ Heart Problems } & & MN \& I & Cdn. Pop & \\
& & 13 & 4 & 3.3 \\
& Female & 10 & 4 & 2.5 \\
\hline Hypertension & Male & 22 & 8 & 2.8 \\
& Female & 25 & 10 & 2.5 \\
\hline Diabetes & Male & 11 & 3 & 3.7 \\
& Female & 16 & 3 & 5.3 \\
\hline Arthritis/ & Male & 18 & 10 & 1.8 \\
Rheumatism & Female & 27 & 18 & 1.5 \\
\hline
\end{tabular}

Source: First Nations and Inuit Regional Health Survey (1999) and National Population According to INCAP, ${ }^{60} 53.4 \%$ of Guatemala's nonindigenous population had access to an indoor bathroom compared with $21.4 \%$ of the indigenous population; only $18.6 \%$ of indigenous households had a sewage connection compared to $43.7 \%$ of non-indigenous households and $50 \%$ of indigenous communities obtained water for household use from wells, rivers and springs. ${ }^{61}$ This reality has two important implications for women's health. First, carrying heavy loads of water long distances places too much strain on women's musculo-skeletal systems, and second, women and their families are more susceptible to intestinal and bacteria-borne diseases as a result of unsafe water.

\subsubsection{Social Instability and Change}

Recent civil wars, natural disasters and population migration in the LAC Region have had both negative and positive effects. On the one hand, they have led to increases in unemployment, poverty, civil and military violence, environmental degradation, and STD/HIV prevalence. On the other hand they have served to increase women's active political participation and female employment, and have often provided a valuable space for challenging existing gender roles. Population migration has also led to an increase in indigenous female-headed households, which though it may give indigenous women more autonomy and standing within the community also increases their daily workload, increasing the likelihood of negative health consequences.

\footnotetext{
${ }^{57}$ Health Canada, 2003

${ }^{58}$ Ibid., 40 .

${ }^{59}$ Health Canada, 1999, 15

${ }^{60} \mathrm{PAHO}, 2002 \mathrm{~b}, 312$

${ }^{61}$ Ibid.
} 
Throughout the 1990s, rural Ecuador underwent three significant changes that altered traditional gender roles: high rates of temporary male migration to urban centers; an increasing 'feminization' of agricultural production and marketing; and population pressure and land scarcity that undermined equitable land inheritance customs. ${ }^{62}$ In Toacazo, men used to control the cooperatives and the agricultural associations where women had neither voice nor vote. ${ }^{63}$ However, once men began migrating to urban centres in search of employment, women in the community gained more access to education, more male assistance with domestic responsibilities from those men that remained in the community, and women are now respected as both participants at the organizational level and as key contributors to a family's health and welfare. ${ }^{64}$ Kichwa women have formed their own organizations and in 2002, three women occupied leadership positions within the local farming organization, the Unión de Organizaciones Campesinas del Norte de Cotopaxi(UNOCANC).

Any analysis of indigenous gender roles and relations in Guatemala must consider the impact of the country's 35-year civil war on the social and cultural structure of indigenous communities. The period 1978-85 is termed "La violencia", due to the intense level of violence perpetrated on indigenous communities, massacres, kidnappings, disappearances and systematic torture and rape of men, women, and children. Female-headed households were uncommon before the conflict, but now $51.2 \%$ of all female-headed households in Guatemala are rural and $56.2 \%$ of these are headed by widows. ${ }^{65}$ The changes brought about by the civil war have had a profound effect on women's health in terms of women assuming tasks traditionally considered to be men's work, the increased levels of domestic violence and mental health problems due to instability, loss of loved ones, rape and torture, and their unstable income and precarious social relations.

However, this has been accompanied by an opening of political spaces to women. Women organized themselves into the first indigenous women's organization in 500 years, The National Coordination of Guatemalan Widows (CONAVIGUA), which supports the relatives of those who "disappeared" during the conflict, especially widows facing economic hardship, and teaches literacy and Spanish. Women have been active in forming new social movements, advocating respect for human rights, pressuring the government to account for the thousands of disappeared persons, challenging the racism of the ladino state and calling for land, housing, health, sanitation and other basic social services. However, since the end of the civil war, many men have accused socially active women of being "gossips" or "prostitutes" in order to discourage them from taking part in community activities, and such participation has become a source of conflict between women and men. ${ }^{6667}$

\subsubsection{Access to Employment and Women's Labour}

Many women in LAC have been forced to migrate to the cities to find remunerated work, usually in the informal or maquila sectors where they are underpaid and underrepresented in national statistics, making them invisible to national planners and worker's unions. In Guatemala, the majority of indigenous women workers are either domestic servants or work in small businesses that are a direct expansion of their domestic roles, such as tortilla making, dressmaking or baking. Indigenous women are usually responsible for communal farming. Still others work in the maquiladora industry, where women make up 80-90\% of the labor force, 54\% of which is between the ages of 15-25. Most of these tasks require little training, education or knowledge of Spanish, but for the same reasons attract little salary or access to credit for business expansion, require long working hours and do not provide access to health insurance, social security or legislative protection. These women oftensuffer physical and sexual abuse in the workplace and receive only $43 \%$ of men's wages. The average income of women in the informal sector is $35 \%$ of the income of women in the formal sector. ${ }^{68}$ Indigenous women's long

\footnotetext{
${ }^{62}$ World Bank, 2000, 40.

${ }^{63}$ Vallejo Real, 2002, 44.

${ }^{64}$ Ibid., 23.

${ }^{65}$ Loughna and Vicente, 1997, 3.

${ }^{66}$ Ibid., 48

${ }^{67}$ Ibid.

${ }^{68}$ Loughna and Vicente, 1997, 31
} 
work hours, combined with their multiple tasks can result in chronic fatigue and headaches as well as other symptoms. ${ }^{69}$

In Ecuador, many indigenous women are employed in the commercial flower industry, and in the mining, shrimp and banana industries, all of which require intensive use of chemical substances that have been identified as health hazards. Researchers and activists have also documented the negative impact of oil companies on the health of indigenous people of Ecuador's Oriente. Oil spills destroy their ancestral lands, polluting their food and water sources. ${ }^{70}$



Figure 2: Indigenous Women's Participation in the Informal Labor Market

Source: Duryea, S. Measuring Social Exclusion. Research Department, IDB, 2001

Inadequate employment, education and living conditions are all correlated with poor nutrition, smoking, unhealthy risk taking behavior, suicide and early pregnancy. AI/AN and Aboriginal women's health needs are not being met due to their inability to access these means to achieving better health. Poverty is endemic among many North American indigenous communities. Among the AI/AN populations, $13.4 \%$ of women aged 16 and older were unemployed in contrast to $6.2 \%$ for the U.S. rate in $1990 .{ }^{71}$ In 1995, the average income of Canadian indigenous peoples was $\$ 17,382$; about 1.5 times lower than the national average of $\$ 26,474 .{ }^{72}$

\subsubsection{Access to Health Care}

Significant barriers exist that prevent indigenous communities from accessing modern or conventional (as opposed to traditional) health care. These barriers fall under two distinct but related categories: a) lack of available health services in or near indigenous communities; and b) indigenous peoples' own unwillingness or inability to access health services when they are available.

\section{a. Lack of Available Health Services}

\section{Coverage of Health Services}

The focus of women's health care in most indigenous communities is usually curative rather than preventive, and focuses almost exclusively on their reproductive health. This ignores the health consequences of women's productive roles and other non-reproductive illnesses, and is less cost-effective than a holistic approach to health care. By focusing on women of reproductive age, they also fail to take into account other important groups of women, such as children, adolescents, and the elderly, and their specific health needs.

In the U.S., only those AI/AN people living on or near reservations are eligible to receive care from the federal government's Indian Health Service clinics and hospitals. It is estimated that only one third of AI/AN permanently reside on or near reservations, whereas one third live in urban areas and the other third move back and forth between the two. Considering that only $2 \%$ of IHS funding serves urban communities, this means that at least half of the AI/AN populations are not served by IHS services, and their health status and access to care have yet to be researched. ${ }^{73}$

\footnotetext{
${ }^{9}$ World Bank, 2000, 19

${ }^{70}$ Yoder, 2002

${ }^{11}$ U.S Department of Health and Human Services, 1999

${ }^{72}$ Health Canada, 2003. 12.

${ }^{73}$ Kingfisher, 1996.
} 
In Guatemala, the health sector is highly centralized. Resources are concentrated in urban centers, even though $60 \%$ of the population lives in rural areas. Guatemala has initiated a process of decentralization of health care to regional administrative units in eight regions. In 1996, the integrated health system launched a campaign to enlist community personnel, including more than 11,500 health guardians, 1,972 traditional midwives and 604 community facilitators. In the rural areas, traveling physicians (visits are infrequent), rural health personnel, nursing auxiliaries, midwives, community facilitators and health guardians attend to indigenous people at the primary level of care. $71 \%$ of health professionals work in hospitals and 54\% of all physicians work in the 21 rural departments of the country. ${ }^{74}$ Coverage of health services reached only $54 \%{ }^{75}$ of the total population and only $25 \%$ of people in rural areas had access. Most indigenous communities are remote and lack the means of transport to access medical centers.

In Peru, there has been an overall increase in available technologies and human resources within the health sector. However, as in Ecuador, health services are concentrated in urban centers with only 2.77 doctors per 10,000 inhabitants at the national level, and only 2.45 in Ucayali. ${ }^{76}$ Indigenous communities are often isolated and only accessible by boat or path, making emergency care almost impossible. The program "Campaña de Salud Integral" (Integral Health Campaign) services the Shipibo community, providing free health care through medical specialists from different fields who travel periodically but infrequently from Pucallpa. Though health professionals staff the local health centers and points situated in the villages, economic problems make some medical services prohibitively expensive, such as X-rays, surgery and even delivery. ${ }^{77}$ Since 1999 , Medecins Sans Frontieres has been working with local NGOs, ${ }^{78}$ the Ministry of Health (MINSA), and the people of Ucayali to train midwives and health promotion agents, and establish a community dispensary to ensure a constant stock of medical supplies. The community manages the dispensary through the health committees, which have overcome mismanagement and organizational problems, but which still face the constraints imposed by poverty. ${ }^{79}$

\section{Quality of Health Services}

High maternal mortality attributable to toxemia, hemorrhages, abortion and other preventable causes indicates severe shortcomings in the health system. Indigenous women say the problem is not with Western medicine itself, but with the way it is administered. In Ucayali, the Ministry of Health (MINSA) lacked adequate equipment and did not always have enough drugs at their disposal, leading to poor treatment of patients.

Many indigenous women that have had institutional births (in hospitals) have complained of poor quality of care. Women prefer giving birth in the home as there they have the psychosocial support of the family and community, whereas in the hospital, although safer, they feel abandoned. It is not unusual in indigenous communities for the husband to be involved in the birth, and his expulsion from the birthing room in hospital settings can often cause stress for the mother. Indigenous women tend to exhaust all traditional therapies before seeking conventional treatment, meaning that most cases seen by modern doctors are already in advanced stages of complication, often beyond prevention, and frequently incurable. ${ }^{80}$

\section{b. Unwillingness to Access Health Services}

Overall, indigenous women are less likely to seek modern health care because:

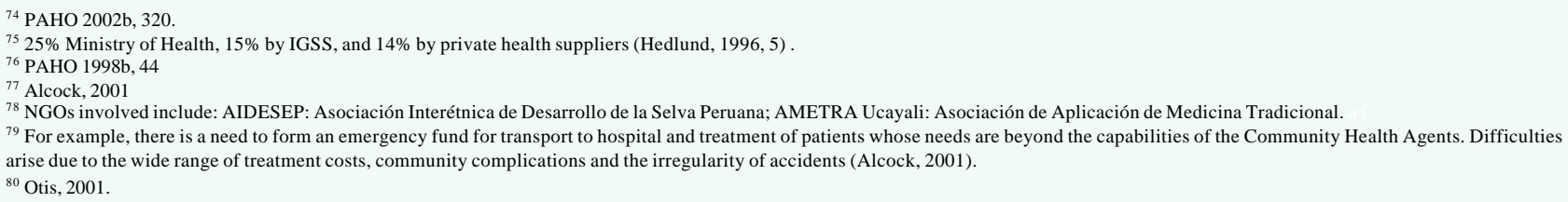




\section{They are more comfortable with their communities' own traditional medical knowledge}

Women are traditionally the providers of medical care and the transmitters of medical knowledge and beliefs in indigenous societies. ${ }^{81}$ Mayan cosmovision conceives of the world as an ordered whole divided in four parts, determined by the four cardinal points, the gods and the colors. Health problems are derived from an imbalance in these cardinal points and are divided between the following causes: homeostatic disequilibrium of the opposites "caliente-frío" (hot/cold - fever, stomach ache), "húmedo-seco" (wet/dry - respiratory infections), dialectic interactions and divine interventions (from spirits such as "mal de ojo" or evil eye), which is related to irritability and diarrhea. ${ }^{82}$

Andean indigenous people regard the individual's health as a reflection of harmony between body, mind and environment. Focus is placed on understanding the causes of the illness, not just curing its symptoms. Sickness is explained in terms of disequilibrium between the individual and their environment and the spiritual world. In the Sierra, these beliefs are summarized in the expression of "mal viento" which refers to bad spirits that cause health problems such as vomit, diarrhea and temperature. ${ }^{83}$ The curandero (healer) will decide whether the illness requires therapy by magic, traditional plants or the "hospital doctor." 84 Of central importance is the role of ceremony in health care and the harmony between mind, body and spirit.

In the US, Canada and Guatemala, women repeatedly mentioned that modern medical practitioners do not usually try to understand or incorporate traditional holistic medical beliefs into their own practices, compromising the quality of treatment that indigenous patients receive. ${ }^{87}$ Women usually prefer to use traditional midwives (comadronas) rather than nurses and doctors, because these women incorporate traditional beliefs and medicinal plants into their work, preserving a connection with the natural and supernatural worlds and their own position of leadership in the community. However, midwives often lack the professional training needed to deal with pregnancy and delivery complications, and some of their methods can even endanger women's lives. ${ }^{88}$ Recently, traditional midwife practices have been associated with high levels of maternal mortality in rural areas, and the Ministerios de Salud in LAC have begun training many midwives in safe birthing techniques. ${ }^{89}$

\section{Box 1 - Canada: Aboriginal women's access to quality health care}

A recent study conducted by the British Columbia Centre of Excellence for Women's Health in the Carrier First Nation reserve community collected First Nations women's opinions on positive and negative experiences with health care personnel. One Aboriginal woman recounted how she had admitted her baby to hospital with a terrible rash while she herself had a black eye from playing fast ball. The hospital staff assumed that her appearance and her baby's rash were a reflection of the fact that she was not a suitable mother, and refused to let her take her baby home. She had to call her doctor to have him confirm her medical history before they would release her baby, which took many days. As a result, she no longer wishes to seek modern medical care...

“. . . I was so hurt. I've never trusted doctors after that because I was very reluctant to bring my daughter in. Anytime she was sick or anything, that incident always comes back to me and I think, I don't want to ever go through that again. I don't want to be judged morally, that I'm a bad mom. I don't want to ever be judged like that again. " 85

Quality service was associated with the doctor sharing knowledge and power with participants over health care decisions, conveying respect for the participants as women with unique cultural heritages, and forming effective interpersonal relationships in ways that reduced the distance between participants and others in relation to the health system. ${ }^{86}$

\footnotetext{
${ }^{81}$ Meentzen, 2000, 17.

${ }^{82} \mathrm{PAHO} /$ WHO/IADB, 1997, 26.

${ }^{83}$ Argüello Mejía, 1988.

${ }^{84}$ Alcock, 2001.

${ }^{85}$ Browne, et al., 2000, 14

${ }^{86}$ Ibid., 21.

${ }^{87}$ The Jambi Huasi (see p.28) was a response to indigenous people's complaints about the treatment they received in modern clinics

${ }^{88}$ For example, in the case of retained placenta, the Shipibo-Conibo midwife may tie the umbilical cord to the woman's toes, which she will then gently pull on to pull out the placenta. Some plants are also used to assist in labor, and sometimes she will manipulate the woman's stomach. The high levels of infant mortality due to tetanus infection can be attributed to the use of unsterilized blades to cut the umbilical cord (Alcock, 2001).

${ }^{89}$ For example, in the past, midwives encouraged women to crouch or sit during the birth, now they make women lie down to protect the baby from being hit in the process. This was met with resistance by a number of women, while others considered it a better way. Some midwives allow the woman to decide which position she will adopt (Alcock, 2001).
} 
Modern health workers often lack the knowledge and understanding of indigenous traditional medicinal necessary to provide culturally sensitive health care. This includes an appreciation of their holistic view of health, which requires that the body, mind and spirit are all balanced and 'healed' simultaneously. Most Western services ignore the spiritual and mental side of physical ailments, and many Guatemalan women expressed that health personnel treat them and the camadronas as inferior, and often do not provide the camadronas with sufficient equipment or training.

\section{They are not understood or are poorly treated by health personnel}

Women cite language barriers as a primary problem - they do not speak Spanish and most health workers do not speak indigenous languages. If the indigenous woman is unable to adequately describe her symptoms and does not understand the doctor's instructions it creates barriers to accurate diagnosis and treatment, which in turn can create bad will between the indigenous community and the health center, preventing other indigenous people from seeking modern health care in the future. Indigenous people's fear and mistrust of modern medicine creates a disincentive for them to obtain preventive treatments such

as cervical cancer screening and vaccinations. Shipibo women confessed to being afraid of dying in hospital, or even being "killed" by the people attending them. One Quiché woman says of her experience, "They left me in the bed alone, there were no other patients in the room and when I felt more pain, I was

afraid because I was alone..." 90

Discrimination and indifference on the part of modern health personnel means that they often do not adequately explain treatments to indigenous patients, and may perceive women to be passive receivers of instructions and information rather than active participants in their own health. Many Shipibo women claimed that MINSA personnel did not perform an examination or explain indications before initiating a contraceptive procedure. In Fujimori's Peru, women suffered involuntary and unhygienic sterilizations, some of which resulted in death. This has been brought to the attention of the Inter-American Commission of Human Rights.

\section{Most health centres have restricted or inconvenient business hours}

Women's daily reproductive and productive labor activities may prevent them from seeking modern medical services, especially when they are faced with long waiting periods at the health centers.

\section{Indigenous men's attitudes prevent women's accessing health services}

Indigenous men may prevent their wives from seeking modern medical services for themselves or their children, largely for the same reasons that women themselves do not seek modern health services. However, when men prevent women from obtaining contraception it represents underlying values about family planning and gendered power

"We have the opportunity to speak with our partners, but between partners, we don't talk about such things. Many women say they are afraid, embarrassed, scared to speak to their husbands [about this topic]. There are many women that never have experienced sexual satisfaction, nor do they know what they feel, they consider it an obligation".

Comadrona Cakchiquel $^{92}$ relationships. In Nicaragua, as in many other LAC countries, it is illegal to deny a woman a sterilization procedure. However, most doctors will not perform it unless the patient brings a note of consent from her husband or an adult male guardian. ${ }^{91}$

\section{Cultural beliefs regarding modesty and sexuality prevent women's accessing health services} Indigenous women's own sense of embarrassment may prevent them from seeking a physical examination, especially by a male doctor. The fact that reproductive health is a taboo subject in Mayan communities makes it impossible at times to educate women on family planning and safe birthing, as they believe that contraception

\footnotetext{
${ }^{90} \mathrm{PAHO} / \mathrm{WHO} / \mathrm{IADB}, 1997,44$.
}

${ }^{91}$ Otis, 2001. 
is only for "mujeres de la vida alegre" (understood to mean "prostitutes"). Women's lack of knowledge about their own reproductive organs and functions also means that they fail to understand and therefore express what assistance they need during pregnancy, delivery and post-partum. ${ }^{92}$ Indigenous midwives are in a process of transition between traditional and modern medicine, and must be central to any women's health strategy, as they can mediate between modern health services and the indigenous community.

\subsection{Health Outcomes among Indigenous Women}

\subsubsection{Reproductive Health}

$\mathrm{AI} / \mathrm{AN}$ women writers have rejected Western portrayals of AI/AN women as being subordinate to men. Many cultures such as the Hopi, Apache and Navajo are matrilineal and preserve a revered position for the reproductive role of women, from which women draw prestige and strength in their communities. In Navajo culture, girls must perform the puberty rite of Kinaaldá upon their first menstruation to celebrate women's reproductive and regenerative powers, her role as a mother and as a woman. After the ceremony is finished, she is no longer a child. Today, the ceremony is one of the most important for the Navajo in terms of cultural continuity. ${ }^{93}$

In Mayan groups, female sexuality is rigidly restricted and most women are denied sexual pleasure, as they are taught to believe that this is only a male entitlement. Many women even complained that their husbands mistreat them and they feel used. ${ }^{94} 95$

The mystery surrounding the subject of sexuality means that most Mayan adolescents do not receive traditional sex education. ${ }^{96}$ This has led to higher incidences of adolescent pregnancy, high fertility levels and shortly spaced births, all of which constitute additional health risks for women.

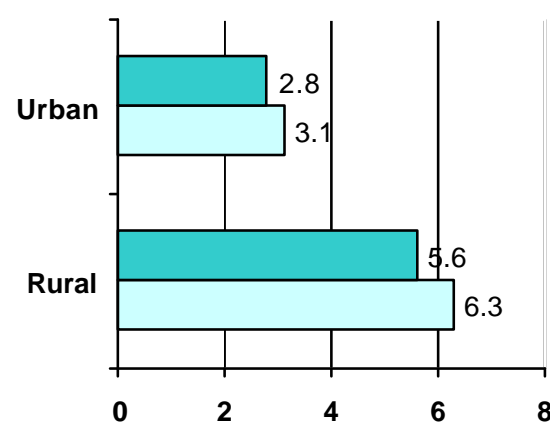

Figure 3: Fertility Rates in Peru

Source: Ministerio de Salud de Peru

\section{High Fertility}

The high levels of fertility among indigenous populations are a result of young age of marriage (14 years old is not unusual), short intervals between pregnancies and long reproductive lives. Guatemalan ladina women have an average of 5.3 children per woman while indigenous women have an average of 6.8 children. In Ecuador, about $21 \%$ of women age 19 in rural areas, as opposed to $15 \%$ in urban areas, have either been pregnant or had a child. ${ }^{97}$ In Peru, although there has been an overall reduction in fertility levels from 1986-1993, the rural fertility rate in 1993 is exactly double of that in urban areas (see Figure 3 ). Figure 4 demonstrates the relationship between fertility and educational levels in Peru (in the general population). Fertility rates are higher among women without any education (5.8 children in 1993) than among women with primary and secondary education (4.9 and 3.1 in 1993).

\footnotetext{
${ }^{92}$ Ibid., 72

${ }^{93}$ Denetdale, 2001

${ }^{94}$ Aguilar and Gonzales, 1994, 24

${ }^{95}$ Ibid (author translation), 24.

${ }^{96}$ Most indigenous communities have their own type of sexual education, but it doesn't cover contraception and HIV/STI transmission. The taboo nature of sex in Mayan culture means that

adolescents do not even understand the reproductive functions completely.

${ }^{97}$ World Bank, 2000, 11
} 
Among the Shipibo, $40 \%$ of women between the ages of $15-19$ and $4.2 \%$ between the ages of $12-14$ are mothers, and their fertility rate is one of the highest at 8.4 children per woman. ${ }^{98} 45.7 \%$ of Native Indian women are under 20 when they have their first child, and teenage pregnancy rates among adolescent First Nations girls under the age of 15 was about 18 times higher than in the general Canadian population (11.0 per 1,000 live births, versus 0.6, respectively). ${ }^{99}{ }^{100}$ Many indigenous people traditionally prefer large families due to the economic utility of a free labor force, and indigenous women often take a passive role in sexual relations so it is their husbands who dictate family size. These women are often unaware of the potential health problems caused by early pregnancies and multiple and shortly spaced births.

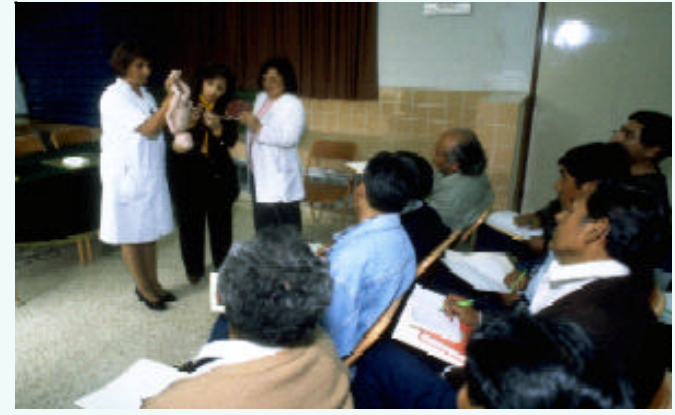

Peruvian men participate in a reproductive health workshop

Armando Waak

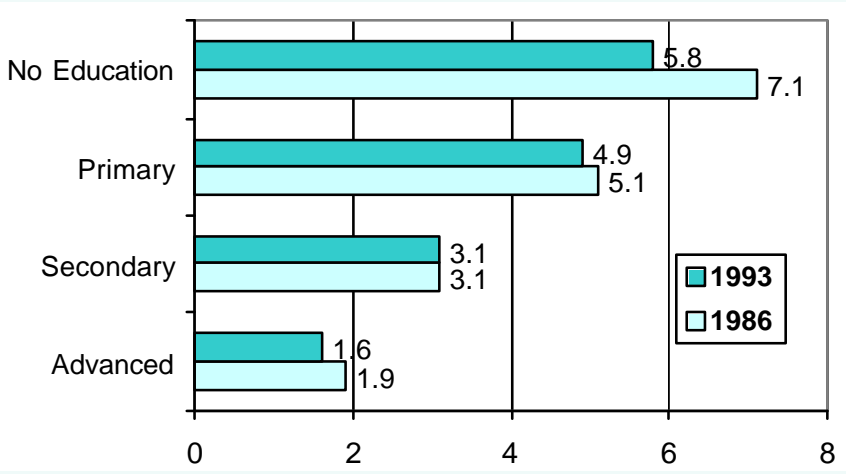

Figure 4 - Relationship between fertility and education Source: Ministerio de Salud de Peru

\section{Contraception and Sterilization}

Among indigenous communities in the region, contraceptive use is almost exclusively the woman's responsibility, which is reflected in high rates of female sterilization and use of contraceptive injections, and low use of condoms and male sterilization. ${ }^{101}$ Mayan women leave the number of children up to fate and often hold misconceptions about the effects of contraception, believing that they create illnesses and lead to birth defects. In general, indigenous people prefer to practice natural or rhythm methods of contraception, although they do not always possess the necessary understanding of women's reproductive cycle. ${ }^{102}$ Condom use among indigenous men is low, which has recently led to an increase in HIV/AIDS and other STIs in some indigenous communities.

In Guatemalan indigenous communities, cultural barriers create a distinction between awareness and use of contraception. In 1995, only 52\% of indigenous Guatemalan women reported having any knowledge of contraceptive methods, in comparison to 93\% of ladina women. A third of those without any education claimed to not know of any contraceptive methods, while $95 \%$ of women who have a primary education did know. However, only $9.6 \%$ of rural indigenous women, compared to $43.3 \%$ of rural ladina women who claimed to know about these methods actually used them. In rural areas of Ecuador, only 54\% of women have received education on family planning methods, even though they reported wanting to reduce their fertility to 3.6 from 4.6 children per woman. ${ }^{103}$

Guatemala has one of the lowest contraceptive use rates at $34 \%$ of the population. When modern methods are used, the most common is female sterilization, with condom use at a low $1.5 \%$ among the general population. Indigenous women tend to associate condoms with extramarital affairs, which discourages them from using them. $41.3 \%$ of Shipibo do not practice any kind of family planning method. ${ }^{104}$ In Ecuador, the most common

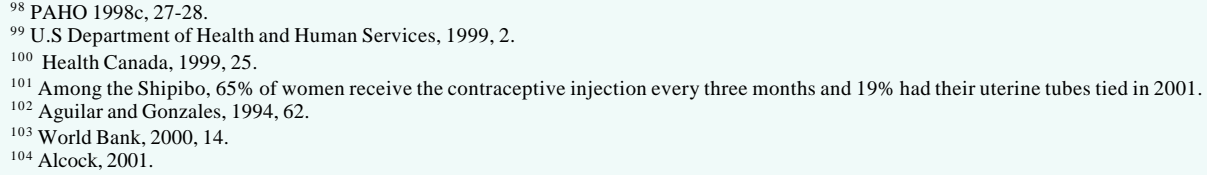


forms of contraception are female sterilization (32\%) and IUD (24\%), while male contraceptives are not frequently used (only 3.0\% of men use condoms and less than $1 \%$ of men are sterilized). ${ }^{105}$ For women who have already had many children and are facing another risky pregnancy, the custom in many LAC countries of requiring male consent for female sterilization can be fatal if husbands refuse consent. In such cases prevailing gender norms and relationships are preventing women from leading healthy, safe lives.

\section{Box 2 - Indigenous Women's Health Status in} Mexico $^{106}$

Chiapas, Guerrero and Oaxaca, where the majority of Mexico's indigenous people live, have the worst reproductive health indicators in Mexico. Maternal mortality rates are at 5.2 per 10,000 births nationally, whereas in Guerrero, they are at 8.3. Most births occur within the home under the supervision of midwives. Women are often afraid to use medical centers because of past negative experiences dealing with health personnel who are unaware of their cultural beliefs. Reproductive health care is seen as a woman's issue, and the pivotal role that men play in deciding when and how the female family members receive care is not recognized. Men's lack of participation is demonstrated by high numbers of tubal ligations in Guerrero at 5,126 compared to 144 vasectomies. $75 \%$ of indigenous women suffer from domestic violence while pregnant, leading to miscarriages or birth complications. ${ }^{107}$ These states also show the highest levels of domestic violence in the country, though many victims do not report crimes due to fear, lack of information on where and how to report, absence of safe houses and other support services, and lack of awareness or inadequacy of existing domestic violence legislation. The Women's Secretariat of Guerrero provides services to domestic violence victims, including a hotline and two safe houses for legal, medical and psychological assistance. The services are provided in both Spanish and indigenous languages. They also plan to work with judges and lawyers to better inform them of domestic violence legislation.

\section{HIV/AIDS/STIS}

The lack of condom use combined with the increased mobility of indigenous populations in search of work makes women particularly vulnerable to infection with HIV/AIDS and other STIs. Many indigenous men migrate to urban centres for work, where they contract HIV/STIs from prostitutes. They then return to indigenous communities and subsequently infect their wives. ${ }^{108}$ Indigenous women usually lack both knowledge of the disease, and the power to demand that their husbands practice safe-sex. The proportions of Aboriginal and AI/AN women with HIV and STIs have also increased in recent years. ${ }^{109}$ In the U.S, women make up $19 \%$ of all AIDS cases, but AI/AN women make up $15 \%$ of all female AIDS cases, compared to $7 \%$ for White women. ${ }^{110}$ Reproductive health programs for women generally exclude men, and fail to address the gender dynamics that shape couple communication and sexual relationships. Increasingly, programs are now targeting men's specific reproductive education and health needs (see Box 4 on the Health Sector Modernization Project in Nicaragua).

\section{Maternal Mortality}

The maternal mortality rate in Guatemala is particularly high at 190 deaths per 100,000 live births. Among indigenous communities, PAHO estimates the rate to be almost $50 \%$ higher and in Petén and the north-west region, it is at least $12.9 \%$ higher. ${ }^{111}$ In 2000, the main causes of maternal death were hemorrhage $(53.3 \%)$, infection (14.4\%) and hypertension (12.1\%). ${ }^{112}$ Maternal mortality is also linked to poor nutrition, and poor prenatal care and attendance during delivery. Approximately $75 \%$ of births in rural areas occur in the home, often in poor hygienic conditions, and attended by a traditional midwife. Trained professionals attend only $3.0 \%$ of births in the country: $10 \%$ of indigenous births and $59.9 \%$ of births in urban areas The lack of medical care during pregnancy (65\% of Guatemalan women did not have prenatal check-ups) and birth have permanent health repercussions for women such as anemia, urinary incontinence, uterine prolapse, genital and urinary infections and vaginal fissures, ${ }^{113}$ all of which are preventable illnesses.

\footnotetext{
${ }^{205}$ World Bank 2000.

${ }^{106}$ Cunningham and Cos-Montiel, 2002 (forthcoming), 14-26.

${ }^{207}$ Ibid., 15-16.

${ }^{108}$ Vrede, 2001

${ }^{209}$ Dion Stout, 1996.

${ }^{10}$ Kingfisher, 1996.

${ }^{11}$ Meentzen, 2000, 34.

${ }^{12}$ Ministerio de Salud Publica y Asistencia Social, 2003, 30

${ }^{113}$ Ibid., 34 .
} 
Rural indigenous women have more at-risk pregnancies because the majority does not receive prenatal care during pregnancy. $50 \%$ of rural Ecuadorian women have less than 5 prenatal visits and $60 \%$ have not received a tetanus vaccination. ${ }^{114}$ A medical professional attends only $56 \%$ of women in rural Ecuador during childbirth, as opposed to $94 \%$ of mothers in urban areas. ${ }^{115}$ 87.5\% of Shipibo women give birth at home attended by a traditional midwife and $6.3 \%$ give birth alone in the forest or at home. ${ }^{116}$ In Ecuador, maternal mortality has been declining on a national level, but remains high at a regional level. In the Sierra region, from 1981-94 there were 250 deaths per 100,000 live births, compared to the national rate of 159 during 1988-94. ${ }^{117}$ Peru has the third highest rate in Latin America and among women with no education it reaches 489 deaths per 100,000 births. ${ }^{118}$

\section{Risk-Taking Behavior}

$20.4 \%$ of $\mathrm{AI} / \mathrm{AN}$ women report that they smoke during pregnancy, compared to $13.9 \%$ of non-indigenous women. There is a strong correlation between smoking and low birth-weight as well as lung cancer. AI/AN women are also three times more likely to drink during pregnancy than non-AI/AN women (i.e. $4.5 \%$ compared to $1.5 \%$ ). Aboriginal women's tendency to binge drink during pregnancy accounts for the high rate of Fetal Alcohol Syndrome and Effects among aboriginal children, which causes stillbirths, low birth weight, and behavioral and learning disabilities in children. ${ }^{119}$ Alcohol abuse as well as poor diet during pregnancy has contributed to the high rates of diabetes, cirrhosis and other liver problems among pregnant women. ${ }^{120}$ It is also closely related, along with the high drug use rate (13.0) among women, with mental health issues including depression, anxiety, suicide and violence.

\subsubsection{Occupational Health}

Indigenous women's concentration in unpaid reproductive work and the underpaid informal sectors (see figure 2, pg.14) means they are at greater risk for health problems related to hazardous working conditions and are not covered by the social security provided to formal sector employees (see Box 5 on Ecuador's Seguro Social Campesino). The impact of oil companies on the indigenous people of Ecuador's Oriente has been well documented. Oil spills and poor disposal techniques have led to cancer, neurological and reproductive complications, the loss of skin, dryness and cracking of skin and change in skin pigmentation. Contamination occurs through the consumption of tainted food or liquids and the inhalation of oil residing on dust or soot particles in the air. ${ }^{121}$ So far, ILO regulatory frameworks for hazardous industries have not been implemented because of financial, educational and cultural constraints. ${ }^{122}$

\subsubsection{Communicable Diseases}

In LAC, a major cause of death continues to be vector-borne diseases and intestinal infections. Women's concentration in rural work makes them more susceptible to diseases such as malaria, cholera and infant mortality rates (IMR). Among Mayans IMR rates are as high as 142/1000 live births, whereas among the ladinos, figures were at 120/1000 live births. Malnutrition is another problem among indigenous children and women. Limited access to land for female-headed households and returnees in Guatemala is largely responsible for this situation,

\footnotetext{
14 World Bank, 2000, 12

115 Ibid.

${ }^{116}$ Alcock, 2001

${ }^{117}$ Ibid.

${ }^{118}$ Meentzen, 2000, 85

${ }^{119}$ A recent study of a First Nations reserve in Manitoba found that 1 in 10 children was the victim of FAS or FAE (Fetal Alcohol Effects), or roughly 100 cases per 1,000 births on the reserve. In contrast, the rate of FAS in western countries is about 0.33 cases per 1,000 births. (Health Canada, 1999, 25).

${ }^{120}$ U.S Department of Health and Human Services, 1999.

${ }^{121}$ Yoder, 2002, 80-97.

${ }^{122}$ Ibid., 20.
} 
as it is elsewhere. Vaccination campaigns have been successful in reducing some of the most common diseases including neonatal tetanus and measles. ${ }^{123}$ However, there is a tendency to not carry through with the full course of treatment.

\subsubsection{Non-communicable Diseases}

The high incidence of cervical cancer among AI/AN women (3.8 deaths per 100,000 women) at 1.5 times the national rate is the result of late diagnosis and poor coverage of screening services. The lack of statistics on cervical and breast cancer among indigenous women of LAC highlights the need for data to be collected on the incidence of these cancers, women's use of preventive measures (such as screening) and what obstacles prevent them from accessing these services. Screening is an important way to detect cancers early on and allow for timely treatment. In order to supply this service to remote communities, the governments of the region will need to consider investing in mobile screening services.

The preceding discussion is summarized in the following table. Due to lack of data, it is impossible to present a complete picture of their health status, and the main regional trends in indigenous women's mortality and morbidity.

\section{Table 5 - Summary of Health Outcomes by Country, Ethnicity and Sex}

\begin{tabular}{|c|c|c|c|c|c|c|c|c|c|c|c|}
\hline \multicolumn{12}{|c|}{ Health Outcomes } \\
\hline COUNTRY & \multicolumn{2}{|c|}{$\begin{array}{l}\text { Indig./Non- } \\
\text { Indig. } \\
(\mathbf{M} / \mathbf{F})\end{array}$} & \multirow[t]{2}{*}{$\begin{array}{l}\text { High Fertility } \\
\text { (\# births/ } \\
\text { woman > } \\
20 \text { yrs age) }\end{array}$} & \multirow[t]{2}{*}{$\begin{array}{l}\text { Under-usage of } \\
\text { contraception } \\
\text { (\% usage) }\end{array}$} & \multirow[t]{2}{*}{$\begin{array}{l}\text { HIV/AIDS } \\
\text { \& STIs } \\
(\% \text { of } \mathrm{F} \\
\text { cases })\end{array}$} & \multirow{2}{*}{$\begin{array}{l}\text { Maternal } \\
\text { Mort. } \\
\text { (deaths/ } \\
\text { 100,000 } \\
\text { live births }\end{array}$} & \multirow[t]{2}{*}{$\begin{array}{l}\text { Heart }^{124} \\
\text { Disease }\end{array}$} & \multirow[t]{2}{*}{$\begin{array}{l}\text { Endocrine } \\
\text { disorders }\end{array}$} & \multirow[t]{2}{*}{ Cancer } & \multirow[t]{2}{*}{$\begin{array}{l}\text { Injury, } \\
\text { violence } \\
\text { (+suicide) }\end{array}$} & \multirow{2}{*}{$\begin{array}{l}\text { Fetal Alcohol } \\
\text { Syndrome } \\
\text { (cases/1,000 } \\
\text { births) }{ }^{125}\end{array}$} \\
\hline \multirow{4}{*}{ Guatemala } & \multirow[b]{2}{*}{$I^{126}$} & M & & & & & & & & & \\
\hline & & $\mathrm{F}$ & 6.8 & $9.6^{131}$ & $\longrightarrow$ & 285 & & & & & \\
\hline & \multirow{2}{*}{ N-I } & M & & $1.5^{132}$ & & & & & & & \\
\hline & & $\mathrm{F}$ & 5.3 & 43.3 & -- & 190 & & & & & \\
\hline \multirow{4}{*}{ USA } & \multirow{2}{*}{ I } & M & & & & & & & & & \\
\hline & & $\mathrm{F}$ & $45.7 \%^{127}$ & $\longrightarrow$ & $15 \%$ & $\longrightarrow$ & 0.80 & $\longrightarrow$ & $0.70 ; 3.8^{13}$ & 3.36 & $\longrightarrow$ \\
\hline & \multirow[t]{2}{*}{ N-I } & M & & & & & & & & & \\
\hline & & $\mathrm{F}$ & - & - & $7 \%$ & 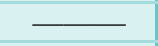 & 91.3 & $\overline{ }$ & $108.0 ; 2.5$ & 6.9 & $\longrightarrow$ \\
\hline \multirow{4}{*}{ Canada } & \multirow{2}{*}{ I } & M & & & & & 13.0 & 11.0 & & & N/A \\
\hline & & $\mathrm{F}$ & $11.0^{128}$ & $\longrightarrow$ & $\longrightarrow$ & $\longrightarrow$ & 10.0 & 16.0 & 59.8 & $67.6^{138}$ & $100^{139}$ \\
\hline & \multirow{2}{*}{ N-I } & M & & & & & 4.0 & 3.0 & & $\longrightarrow$ & N/A \\
\hline & & $\mathrm{F}$ & 0.6 & $\longrightarrow$ & $\longrightarrow$ & $\longrightarrow$ & 4.0 & 3.0 & $\underline{-}$ & $\overline{ }$ & $0.33^{140}$ \\
\hline \multirow{4}{*}{ Peru } & \multirow{2}{*}{ I } & M & & $\overline{ }$ & & & & & & & \\
\hline & & $\mathrm{F}$ & $5.6 ; 8.4^{129}$ & $41.3 \%$ don't use ${ }^{133}$ & $\longrightarrow$ & $\longrightarrow$ & & & & & \\
\hline & \multirow{2}{*}{ N-I } & M & & $\longrightarrow$ & & & & & & & \\
\hline & & $\mathrm{F}$ & 2.8 & & $\longrightarrow$ & $489^{136}$ & & & & & \\
\hline \multirow{4}{*}{ Ecuador } & \multirow[t]{2}{*}{ I } & M & & $\longrightarrow$ & & & & & & & \\
\hline & & $\mathrm{F}$ & $21 \%{ }^{130}$ & $\longrightarrow$ & 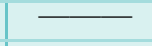 & 250 & & & & & \\
\hline & \multirow{2}{*}{$\mathrm{N}-\mathrm{I}$} & M & & $4 \%{ }^{134}$ & & & & & & & \\
\hline & & $\mathrm{F}$ & $15 \%$ & $56 \% 135$ & 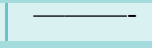 & 159 & & & & & \\
\hline
\end{tabular}

NB: These data come from various sources and are related to different time periods, making comparisons difficult. Dotted lines mean the data was notavailable.

In particular, more information is needed on: HIV/AIDS/STIs and other reproductive health complications; women and men's sexual and reproductive health behaviour, including both health seeking and risk-taking behaviour; barriers to contraceptive use in indigenous communities; occupational health (including the health 
impact of women's reproductive and domestic labor); the incidence of communicable and non-communicable diseases among indigenous communities; and women's access to quality health services.

\section{Addressing Indigenous Women's Health}

\subsection{International and National Legal Frameworks}

Most countries have signed various international treaties, declarations and laws, including the Declaration of Human Rights (1948), and the Resolutions of the Americas Summit (1994), but the ILO Convention 169 on Indigenous and Tribal Peoples (1989) is by far the most extensive in terms of provisions for social security and health. ${ }^{141}$ Other legal documents include the Agreement for the Construction of a Development Fund for Indigenous People of Latin America and the Caribbean (1992), the International Decade of the World's Indigenous Peoples (1995-2004) adopted by the UN General Assembly, and the Agreement between the Indigenous Parliament of America and the Pan-American Health Organization (1995). ${ }^{142}$

Various countries (Bolivia, Colombia, Ecuador, Mexico, Nicaragua, and Paraguay) have revised their Constitutions to legally recognize the rights of indigenous people to maintain and promote their specific cultural, linguistic and territorial integrity. Others (Bolivia, Chile, Colombia and Guatemala) have emitted laws and reforms favorable to their indigenous populations. In Guatemala, the Acuerdos de la Paz included an Accord on the Identity and Rights of Indigenous People, which was considered to be unique in the history of Latin America at the time. It pledged to eradicate discrimination, made harassment of indigenous women a crime, created an organization to defend the rights of indigenous women and to educate the population on indigenous men and women's rights, and guaranteed their compliance with the ILO Convention 169. ${ }^{143}$ Among the barriers to implementing these agreements have been health sector reforms which focus on cost recovery measures and cuts in health expenditure. These tend to disproportionately affect women because: a) women require more health services due to their reproductive function; b) the reforms increase the informal burden of health care that women already provide for their families and communities; c) women have less access to employment and income that allow them to purchase/participate in health insurance schemes; and d) despite the fact that women provide most formal and informal health care, they are underrepresented at the level of health policy planning and resource allocation.

\footnotetext{
${ }^{123}$ Hedlund, 1996, 6.

${ }^{124}$ Heart Disease, Endocrine Disorder, Caner and Injury and Violence cells: 1) for U.S.: White mortality rate/ 100,000 is shown in N-I cells \& the AI-AN-White ratio is shown in the cells

referencing indigenous men and women, 2) for Canada: data show morbidity by percent of prevalence for heart disease and endocrine disorders and as no. of deaths per 100,000 women for cancer and violence rates

${ }^{125}$ Numbers represent combined total of FAS cases for male and female children and are referenced in the female cells for convenience only

${ }^{126} \mathrm{I}=$ Indigenous and $\mathrm{N}-\mathrm{I}=$ Non-indigenous people. $\mathrm{M}=$ Male and $\mathrm{F}=$ Female

${ }^{127} 45.7 \%$ of Native Indian women are under 20 when they have their first child

${ }^{128}$ This rate is per 1,000 live births e.g. 11 children per $1,000 \mathrm{LB}$

${ }^{329}$ The Shipibo women of Eastern Peru have one of the highest fertility rates in the country at 8.4 children/ woman. The average number is 5.6

${ }^{130}$ Shows the percent of women in rural areas less than 19 years of age who have been pregnant or had a child; $15 \%$ refers to women in urban areas. This is therefore a rough approximation of indigenous and non-indigenous birth rates

${ }^{131}$ This figure represents percent of rural indigenous women, vs. percent of rural ladina women $(43.3 \%)$

${ }^{232} 1.5 \%$ usage of condoms amongst the general population (e.g. including indigenous populations)

${ }^{333}$ This figure applies to the Shipibo of Eastern Peru only

${ }^{134} 3 \%$ use condoms and $1 \%$ are sterilized in the general population (e.g. including indigenous people)

$53532 \%$ undergo female sterilization and $24 \%$ use IUDs in the general population

${ }^{136}$ This refers to the total number of deaths per 100,000 live births among women with no education (also includes indigenous women).

${ }^{137} 3.8$ maternal deaths per 100,000 women are indigenous women vs. 2.5 deaths per 100,000 on a national level

${ }^{138}$ This figure includes the suicide rate of $12.4 / 100,00$ women

${ }^{139}$ This figure relates to the Manitoba reserve only

${ }^{140}$ The statistic, 0.33 , relates to the average rate in Western countries in general

${ }^{41}$ Alderete, 1999,10

${ }^{242}$ Ibid: 10

${ }^{43}$ Meentzen, 2000, 8
} 


\subsection{International Cooperation}

Most projects on indigenous people's health continue to be funded by international aid agencies such as PAHO, the World Bank and the Inter-American Development Bank. In 1993, the World Health Organization and PAHO adopted the Health of the Indigenous Peoples Initiative, which promoted 5 key principles:

- The need for a holistic approach to health,

- The right to self-determination of indigenous peoples,

- The right to systematic participation,

- Respect for and revitalization of indigenous cultures

- Reciprocity of relations. ${ }^{144}$

The Indigenous Women's Health Project in Guatemala is the only project to date that PAHO has carried out specifically on indigenous women's health. The valuable lessons learned and progress achieved need to be utilized in the formation of similar projects in the Region. Both the World Bank and the Inter-American Development Bank have been very active in indigenous people's development, poverty alleviation and health. They have also undertaken specific projects and subcomponents of projects in larger programs on gender or indigenous women's health and political participation. ${ }^{145}$

\subsection{Indigenous Women Organizing}

\section{Box 3 - Guatemala: Participation of Indigenous} $\underline{\text { Women }}^{146}$

In 1992, The Pan-American Health Organization began "Education and Self-care in Health as a Means to Strengthen the Participation and Leadership of Indigenous Women in Eight Communities in Guatemala". The project aimed to empower indigenous women and improve their awareness of health issues by promoting their participation in health projects in four K'iché and four Kaqchikel communities. It was jointly implemented by the $\mathrm{MOH}$ and indigenous women to strengthen collaborative efforts, ensure sustainability, and included both the participation of bilingual women (to foster communication between different ethnic groups) and the existing health services that work with indigenous populations and have indigenous staff. Other goals included the development of participants' gender identities and upgrading the training of health services staff to include gender and ethnicity. PAHO helped strengthen the Indigenous Women's Councils, who by 1999 had acquired the necessary skills to conduct literacy workshops, become health promoters, develop projects, process and correctly use medicinal plants, design and print materials and organize a radio program to disseminate health information to their community.

Indigenous women have been organizing and lobbying their governments to improve their own and their communities' health status for many years. Among the most famous indigenous rights activists is the Nobel Laureate Rigoberta Menchú, whose foundation carries out projects directed at education, health care, and human rights, with an emphasis on women's civil rights. In Ecuador in January of this year, the First Ecuadorian Indigenous Women's Assembly met to discuss how to increase indigenous women's participation in national politics, in the indigenous movement in Ecuador and how to improve their Leadership Training Center for Women "Dolores Cacuango", which trains indigenous women in how to organize, direct and be promoters in their communities. They now have 78 leaders in 12 of the Sierra provinces. ${ }^{147}$

In August 2003, MAM Línea Fundacional of Peru completed a six-week training program for 215 participants comprised of obstetrician students, NGO workers and rural indigenous women. This women's activist network focuses specifically on women's sexual and reproductive rights and coordinates activities that educate rural women and advocate on their behalf to improve their health status. They have been one of the most active organizations in Peru to advocate for justice for the many rural and indigenous women that were forcibly sterilized in the late 1990's.

\footnotetext{
${ }^{144}$ PAHO, 2003, 5

${ }^{145}$ See PROLEAD (IDB) and PRODEPINE (WB) for examples of these projects

${ }^{146}$ PAHO, 1999.

${ }^{147}$ This is run by the Confederación de Pueblos de la Nacionalidad Kichwa de Ecuador (ECUARUNARI) see: http://southasia.oneworld.net
} 
In the U.S., the Native American Women's Health Education Resource Center on the Yankton Sioux Reservation (Ihanktonwan) provides services on health, reproductive health and rights, environmental protection, cultural preservation, sovereignty, treaty rights, and violence against women. They are lobbying the U.S. government to improve the services offered by the Indian Health Service, including informed consent in sterilizations, rights to practice traditional healing and medicine and regain women's 'traditional' decision-making power in the household and the economy. ${ }^{148}$ The Lakota Winyan Wo Traditional Birthing Education Pilot Project (Pine Ridge and Rosebud Sioux Reservations, South Dakota) is part of the Indigenous Women's Network's Healthy Communities and Healthy Bodies Programs. The project, which started in September 2002, captures and passes on the elders' knowledge of traditional cultural protocols and birthing methods through a curriculum to teach Lakota women aged 10-18 about Lakota birth education. Their goal is to reduce the number of young mothers receiving cesarean sections by teaching girls to make informed family planning decisions and teaching them to use and honor their grandmother's traditional knowledge. ${ }^{149}$

In November 2002, Oaxaca, Mexico hosted the first Indigenous Women's Summit of the Americas over a 5-day period. The delegates issued a set of priority action areas for the international community and their own NGOs and cooperatives to work towards in the near future. They released a declaration that established, among other issues:

- That women have the right to participate fully in the decision-making process on community development issues;

- That indigenous women continue to live under conditions of great discrimination, racism, extreme poverty, exclusion and lack of access to power, reflected in the inequalities in labor markets and access to fair wages;

- That the richness of their Peoples has its origins in the transmission of values through community education, in which women have played a central role as midwives, counselors and spiritual guides, allowing the transmission of their traditional values and teachings, which are crucial to the development of health models that are in keeping with their cultures and traditions;

- That education for indigenous women is critical for their collective development, understanding the need to promote intercultural education in their own languages and with their own cosmovisions;

- That indigenous women have gained a voice in international forums in the last few years where they have clearly stated their demands; however, this has rarely resulted in an overall improvement in the realities faced by indigenous communities, and particularly indigenous women;

- That violence, trafficking, and forced prostitution of indigenous women and children in the Americas has increased, in part through increasing militarization and armed conflict;

- That to ensure the full and effective participation of indigenous women, they must take control of the development of alternative solutions for their problems, including raising awareness among indigenous men;

- That indigenous peoples working in various political, economic, social and cultural spheres often encounter problems incorporating a gender perspective into their ongoing work plans and policies, resulting in the undermining of the input of indigenous women in indigenous organizations. ${ }^{150}$

\subsection{Recommendations}

A number of positive experiences already demonstrate the effectiveness of including a gender and women's rights perspective into programs that address the health of indigenous peoples.In order to improve indigenous women's health however, health planners and policy-makers will have to address existing attitudes and beliefs; structural, cultural, legal and economic inequalities; indigenous women's own agency and participation; and data collection and information gathering.

\footnotetext{
${ }^{48}$ Interview with Charon Asetoyer, Executive Director, March 2002 http://www.feministcampus.org/network/chat/chat_charon03062002.asp

${ }^{249} \mathrm{http}: / / \mathrm{www}$.indigenouswomen.org/programs2/content.htm\#healthy

${ }^{50}$ First Indigenous Women's Summit of the Americas Declaration and Platform of Action, 2002.
} 


\subsubsection{Recommendations for Health Policy Planners in Governments and Donor Institutions}

Increase indigenous women's economic capacity and ensure their equal participation in the labor market This includes: providing indigenous women with the training, education and credit they need to enable them to start their own businesses or gain access to the labor market, while ensuring that indigenous women receive equal wages for equal work; providing legal recourse for indigenous women facing hazardous working conditions and abusive treatment in the informal sector, including regulation of domestic services labor, maquiladoras and farm labor and providing social security and health insurance to those indigenous women in the informal sector.

Promote agrarian reform that includes women's participation in decisions on land distribution and titling National Governments must promote land-titling reforms for indigenous communities and families to ensure that they have access to the plants for their medicines and their traditional forms of subsistence. Since indigenous women are key actors in family nutrition and the preservation of traditional medicinal knowledge, their views should be included in these processes.

\section{Box 5 - Ecuador: Seguro Social Campesino (SSC) ${ }^{151}$}

The Inter-American Development Bank (IADB) and the Ecuadorian Government are working together to reform the 35 year-old SSC program, recognized as one of the first schemes to provide low cost health services to the informal rural sector (mainly indigenous communities) while ensuring active community participation. Coverage reaches $8 \%$ of the total population and in 2001 it was to be extended to the entire rural population by incorporating contributions from private and public insurance plans. Working in consultation with the National Directorate for Indigenous People's Health, the IADB will provide resources for the training of SSC staff and farmers' associations in health promotion and preventive care with a focus on nutrition and culturally appropriate maternal and infant care. They will also finance a medical equipment and medicine supply system to ensure the constant availability of medications and technologies.

Ensure that all indigenous communities have access to affordable, quality, culturally, and gender-sensitive health services

Adequate health services should expanded to all rural communities in accordance with their need. Doctors and nurses should be provided with the necessary incentives to locate themselves in rural areas, as well as the language and cultural training necessary to adequately serve indigenous communities, and work with traditional healers.

An adequate supply of both modern and traditional medicines and basic supplies, including contraceptive methods should be available to indigenous communities. Indigenous health workers (such as midwives) should be provided with access to nursing and medical schools and the necessary equipment and supplies to implement that training.Having more indigenous women health providers on staff would most likely increase their use government health services. All of these basic needs must be met before new health technology is discussed.

\section{Improve data collection and research on indigenous communities}

Health data should be disaggregated by sex, ethnicity, region of residence, age, and socio-economic status so that a complete picture of the health status and needs of indigenous communities can be used to guide allocation of financial and human resources, the design of policies, programs and health interventions and the delivery of services. Once this data is collected, researchers and policy analysts will need to use this information to monitor whether services and funds are being equitably allocated among population groups and meeting their health needs. More anthropological information is also needed about the social construction of gender in indigenous communities, and the physical and mental health impacts of women's gendered social roles.

\footnotetext{
${ }^{151}$ IADB, 2002.

${ }^{152}$ World Bank, 2003 (forthcoming).
}

${ }^{153}$ El Comercio, 1996. 


\subsubsection{Recommendations for Health Workers and Project Managers}

\section{Incorporate a gender perspective into all programs and services that target the health of indigenous communities.}

Acknowledge and address the differences in women and men's health status and determinants. Provide indigenous men with training on non-violent methods of conflict resolution from an early age. Educate both women and men on their right to live free of violence and right to determine the number and spacing of their children. Teach indigenous women about their human and legal rights.

Box 6 - Ecuador: The Jambi Huasi ${ }^{153}$

In Otavalo, Ecuador, the Federación Indígena Campesina de Imbabura and UNFPA have successfully combined traditional medicine with hospital treatments to respond to the demands of indigenous organizations for more culturally appropriate medical care. The Jambi Huasi ("House of Health" in Quechua) is a health center with a pharmacy (which dispenses both traditional and modern medicines), delivery rooms, laboratory, six medicinal plant gardens, a midwife, an outreach and education program, reproductive health program, two medical doctors, a health promoter, a yachag (shaman), an ambulance to take emergency cases to the local hospital, a steam room and a dentist's office. The doctor and the healer work side by side, but not together. The yachag is in charge of treating illnesses that cannot be explained scientifically, and conventional doctors (all of which are indigenous women) attend all cases the yachag cannot cure. By 1998 the center was attending close to 10,000 patients per year. The staff travels by van to remote mountain communities to provide medical and educational services to indigenous men and women, which has led to an increase in contraception use from $10 \%$ to $40 \%$ among these communities. The result has been a marked reduction in maternal and infant mortality in Otavalo.

\section{Involve indigenous men}

Reproductive and sexual health programs and services should be targeted to both men and women, to educate them about safe pregnancy and delivery, HIV/AIDS and STIs, and family planning. Male involvement and awareness should be encouraged so that men acknowledge their joint responsibility for their own, their partners', and their families' sexual and reproductive health.

\section{Box 4 - Nicaragua: The Health Sector Modernization Project ${ }^{152}$}

The World Bank and the Nicaraguan Ministry of Health $(\mathrm{MOH})$ are in the second stage of the "Health Sector Modernization Project" which aims to improve the health of the poorest sectors of society that present the highest levels of maternal and infant mortality. A sub-component of the Strengthening Primary Care in Health and Nutrition program encourages indigenous women to analyze their gender roles in order to improve equity and overcome linguistic barriers. They have also constructed a number of Maternal Homes in the predominantly indigenous regions of the Atlantic Caribbean Coast which are run by community committees. Women spend 15 days in the maternal homes where they are provided with information on family health care, self-esteem and the promotion and use of women's rights, as a major problem is their high fertility and lack of self-esteem which prevents them from caring for their health. The program has seen the participation of $60 \%$ of husbands in educational sessions regarding safe birthing practices, nutrition of pregnant women, family planning methods and the care of children and the home while the woman is incapacitated. In the end, $50 \%$ of the men trained actually participated in the care of children and the home while their wife was in the maternal home.

\section{Adopt a holistic, life-cycle approach to indigenous women's health care}

This includes looking at indigenous women's health from a preventive, life-cycle perspective, acknowledging the multiple, and non-reproductive health risks faced by women of every age, especially the health risks posed by domestic violence. Immunization, screening and testing services (for illnesses like breast and cervical cancer) must be provided to indigenous communities, and domestic violence hotlines, safe houses and support groups should be established to help women living in violent situations. Maternal homes have been shown to reduce reproductive risk and maternal mortality among indigenous women, while educating both the parents on parenthood, reproductive health, contraception, and family planning. 


\section{Box 7 - Canada: Indian Health Transfer Policy}

The Canadian government has been devolving control of Aboriginal health care to the communities themselves through their "Indian Health Transfer Policy," in response to calls from Aboriginal communities for health services that utilize their traditional medical beliefs and practices. $84 \%$ of First Nations Communities are already involved in the First Nations Control Process. Under the agreement, the government will provide funding and technical advice but the community will be responsible for program design and service. The communities are restricted in the type and scope of health programs which they can implement, but women of the William Charles Band in Saskatchewan report that having services that are more responsive to their needs and values has made them feel more secure about their health. ${ }^{154}$ Women play a central role in providing traditional medical treatment and in a number of places, such as in the Inuit community of Povungnituk, Quebec, they are leading efforts to establish complementary medicine in an "Indigenous Midwifery Program where Inuit midwives provide a full range of care."155

\section{Involve indigenous women in all attempts} to address their health and social status

Indigenous women are politically and socially active at the local, national and regional levels, as indicated by the recent Indigenous Women's Summit of the Americas, but their voices and concerns are not adequately integrated into national and local health policies and services. Both health workers and policy planners need to devise means to work with existing indigenous women's organizations as a strategy to access existing resources and traditional healthcare knowledge and thereby avoid redundant programs and increase indigenous women's participation in healthcare planning and delivery.

\section{Conclusion}

Throughout the Americas, indigenous women suffer from high rates of domestic violence, mental health problems, reproductive health risks and complications, and nutritional deficiencies, pointing to a common history of deprivation among indigenous communities in the Americas. Most of these health problems are preventable and a result of gender inequality, poor quality of health services, lack of access to services, and fear and mistrust of modern health services. Women's traditional gender roles and relationships assign them a triple workload that makes it difficult for them to find the time and means (both economic and logistic) to seek modern health care. Although traditional medicine and midwives have done little to lower the high rates of maternal mortality among indigenous women, they have also healed indigenous people for hundreds of years. For indigenous communities, traditional medicine is integral to the harmony of mind, body and spirit and therefore will and ought to play a central role in any health strategy they adopt.

In the future, international agencies, national governments and local women's organizations should collaborate more closely to identify and address the health needs of indigenous communities, and particularly indigenous women. Sector-wide approaches do not always capture the context in which health care is administered and received by the population, and filtered through gender inequities and power relations that often deprive women of their health rights. Projects should extend the concept of women's health beyond reproductive health to encompass all of the health hazards women face throughout their life cycle. Health programs and services should focus not only on curative treatment, but also on preventive medicine and education campaigns, targeting reproductive health, vaccinations, hygiene, child health and midwifery. In this regard, the inclusion of men in reproductive health education and anti-domestic violence programs will be essential to address the underlying causes of health problems and their long-term cure. Attention should also be given to strengthening the organizational abilities of indigenous women, their ability to gain political leverage and to resolve inequities in their own communities. There are many challenges ahead, but much progress has been made and, in the majority of successful cases, the catalysts have been indigenous women themselves.

\footnotetext{
${ }_{255}^{154}$ Dion Stout, 1996.
} 


\section{References}

Aguilar, A.L and Gonzales, J.H. 1994 Concepciones y Practicas de Salud Reproductiva de las Mujeres de las Comunidades K'íche' y Kaqchikel OPS/ Ministerio de Salud Pública y Asistencia Social Guatemala. Guatemala: OPS.: 24

Alcock, G 2001 Socio-cultural Aspects of Health: Women of childbearing age. Results from Missions in Ucayali, Peru. A Medecins Sans Frontieres Report, http://www.msf.org/countries/page.cfm?articleid=4996B6DA-2383-420B-A5D2547956A6B465

Alderete, E (Wara) 1999 The Health of Indigenous Peoples: Sustainable Development and Healthy Environments(SDE) and Health in Sustainable Development(HSD) Washington,

D.C. : WHO

Argüello Mejía, S 1988 “Etiología de la Medicina Tradicional Ecuatoriana. El Caso del mal aire” In Nuevas Investigaciones Antropológicas Ecuatorianas Eds. S. Argüello and L. McKee, Quito: Editorial Abya-Yala

Browne, A. J, Fiske, J.A, Thomas, G. 2000 First Nations Women's Encounters with Mainstream Health Care Systemsand Services Vancouver: British Columbia Centre of Excellence for Women's Health

Center of Studies and Information of the Multiethnic Woman, CEIMM of the University of the Autonomous Regions of the Caribbean Nicaraguan Coast, URACCAN 2002, Background Paper on Gender from the Indigenous Women's Perspective First Indigenous Women's Summit of the Americas Oaxaca, Mexico Nov 30- Dec 4 2002: 22,

http://www.mujeresindigenas.net/documentos de discusion/ingles/genero-desde-la-vision-de-las-mujeres-indigenas-ingles.doc

Correia, M and Pena, V. 2002 Panorama de Género en América Central Washington, D.C.: Región de América Latina y el Caribe Banco Mundial.

Cunningham, W. \& Cos-Montiel, F. 2002 (forthcoming) Crossroads of Gender and Culture: Impediments to Economic Development in Oaxaca, Chiapas and Guerrero Washington, D.C.: World Bank:14-26

Denetdale, Jennifer Nez. 2001. "Representing changing woman: a review essay on Navajo women" in American Indian Culture and Research Journal v. 25 no.3 (2001) http://www.sscnet.ucla.edu/indian/

Dion Stout M. 1996Aboriginal Canada: Women and Health in Canada-U.S.A. Women's Health Forum http://www.hc-sc.gc.ca/canusa/papers/canada/english/indigen.htm

El Comercio, May 15 1996, Otavalo: las mujeres curan con la tradición in the C Sociedad section (photocopy in PAHO archives)

First Indigenous Women's Summit of the Americas Declaration and Platform of Action Nov. 30- Dec. 42002. http://www.mujeresindigenas.net/documentos de discusion/declaracion mujeres english.htm

First Nations and Inuit Health Branch, 1999 A Second Diagnostic on the Health of First Nations and Inuit People in Canada, Health Canada. http://www.hcsc.gc.ca/fnihb/cp/publications/second diagnostic fni.htm

First Nations and Inuit Health Branch 2003 A Statistical Profile on the Health of First Nations in Canada $\underline{\text { http://www.hc-sc.gc.cal }}$ fnihb-dgspni/fnihb/sppa/hia/publications/statistical_profile.pdf

Garcia-Moreno, C.1998 Gender and Health: A Technical Paper Geneva: World Health Organization.

Guerra, Gigi, 2001 "Beating women is a way of life here" In Jane Magazine February 2001 http://www.unfpa.org/focus/ nicaragua.msmagazine.htm

HealthLink -Medical School of Wisconsin “ Women's Health Week Focuses on MinorityFemales” May 102002 http://healthlink.mcw.edu/article/1021047874.html

Hedlund, K 1996 Indigenous women's health in Guatemala: A case study on the interrelations between indigenous women and local health workers in four selected municipalities. Bachelor's Thesis in Public Health . Stockholm: Karolinska Institutet

Hinrichsen, D. August 21 2000, “Taking Health to the High Sierra” In People and the Plane: The Ecology of Hope Vol. 8 No. 4, London

IADB, Perfil de Facilidad Sectorial - Ecuador: Fortalecimiento del Seguro Social Campesino 25 de Junio del 2002.

$\underline{\text { http://www.iadb.org/exr/doc98/pro/pec0101.pdf }}$

Indian Health Service, 1999. Indian Health Focus - Women. U.S. Department of Health and Human Services, Indian Health Service http:// www.ihs.gov/NonMedicalPrograms/IHS Stats/files/women1998.pdf

Kingfisher, P. 1996 The Health Status of Indigenous women of the U.S.: American Indian, Alaska Native and Native Hawaiians. Health Canada http://www.hc-sc.gc.ca/canusa/papers/usa/english/indigen.htm 
Loughna, S \& Vicente, G. 1997 Population Issues and the situation of women in post-conflict Guatemala. ILO Action Programme on Skills and Entrepreneurship Training for Countries Emerging from Armed Conflict. Geneva: Training Policies and Systems Branch, ILO

Meentzen, Angela. 2000 Estrategias de desarrollo culturalmente adecuadas para mujeres indígenas (primer borrador). Unidad de Pueblo Indígenas y Desarrollo Comunitario, Departamento de Desarrollo Sostenible. Washington, D.C.: Banco Interamericano de Desarrollo.

Ministerio de Salud Pública y Asistencia Social, 2003 Informe Final Línea Basal de Mortalidad Materna para el año 2000, Guatemala: Ministerio de Salud Pública, Programa Nacional de Salud Reproductiva, OPS

Moser, C. 1993.Gender Planning and Development: Theory, Practice and Training. New York: Routledge,

Otis, Ginger, 2001 “Casas Maternas” In Ms. Magazine April/May 2001 found in "Personalizing Population” UNFPA. http://www.unfpa.org/focus/nicaragua/casasmaternas.htm

PAHO, 2002a Gender Equity in Health Advocacy Kit, Washington, D.C.: Gender and Health Unit, PAHO, http://www.paho.org/english/hdp/hdw/ GEHPaper.pdf

1992 Health and Development of Indigenous Quiche and Cakchiquel Guatemalan Women - National Project. Washington, D.C.: PanAmerican Health Organization

1998a Salud en las Americas, Volume I, Volume II. Washington, D.C.: PAHO.

D.C.: PAHO

1998b Situación de Salud de los Pueblos Indígenas de Perú of the Iniciativa de Salud de los Pueblos Indígenas de OPS. Washington,

1999 Leadership and Participation of Indigenous Women in Health Education and the Promotion of self-care in Guatemala Washington,

D.C.: Women, Health and Development Unit, PAHO.

2002b Salud en las Americas Volume II, Washington, D.C.: Pan-American Health Organization

2002c "Shared Agenda for Health in the Americas - Multilateral Partnerships" In Partnerships for better health in the Americas December 2002 Washington DC http://www.paho.org/English/DEC/OP11-Multilaternal.pdf

2003 Strategic Directions and Plan of Action 2003-2007, Washington, D.C.: Health of the Indigenous Peoples Initiative, PAHO

PAHO/WHO/IADB, 1997, Etnicidad, Salud y Riesgo en Guatemala. Guatemala: OPS/OMS

Vallejo Real, Ivette 2002 "Estudio de Caso en el Pueblo Kichwa de Toacazo-Cotopaxi" in Proyecto Estudios de Caso Sobre Identidades y Roles de Género en Pueblos y Nacionalidades del EcuadorPrograma de Género y Patrimonio Cultural de PRODEPINE, World Bank

Vrede, Ifna. Facing Violence against Women in Indigenous Communities: The Case of Marroon Communities in the Brokopondo District in Suriname. Presentation at the "Symposium 2001: Gender Violence, Health and Rights in the Americas" Cancun, Mexico June 4-7, 2001.

World Bank, 2000 Ecuador Gender Review: Issues and Recommendations, Washington, D.C.: World Bank

World Bank (forthcoming) 2003 “Nicaragua -Programa de Modernización del Sector de Salud PMSS” In World Bank Projects: Directory of Gender Experiences in World Bank Financed Projects in Ecuador and Central America Washington, D.C.: World Bank

Williams, D.R 2002 “Racial/Ethnic Varations in Women's Health: The Social Embeddedness of Health" In American Journal of Public Health, April 2002, Vol. 92, No. 4 APHA

Yoder, Brandon 2002 “Indigenous People and Oil Production in Ecuador's Oriente”. In Forth World Journal Vol. 5 No. 1 pgs 80-97. Olympia: Center for World Indigenous Studies. 